\title{
THE EFFECTS OF HIGH SCHOOL CURRICULUM ON EDUCATION AND LABOR MARKET OUTCOMES
}

Joseph G. Altonji

Working Paper No. 4142

\section{NATIONAL BUREAU OF ECONOMIC RESEARCH 1050 Massachusetts Avenue}

Cambridge, MA 02138

August 1992

This study was funded by the National Center on Education and Employment, Teachers College Columbia University under a grant from the US Department of Education, by the Spencer Foundation, and by the Center for Urban Affairs and Policy Research at Northwestern University. I thank John Bishop, Eric Hanushek, Bruce Meyer, Aaron Pallas and participants in seminars at Boston University, Cornell University, the University of Kentucky, Northwestern University, the Ohio State University, Princeton University, the University of Pittsburgh, Teachers College Columbia University, Texas A\&M, and the Institute for Research on Poverty for helpful comments. Avner Greif, Christian Stadlinger and James Spletzer provided excellent research assistance. I am solely responsible for the opinions expressed in the study and for any errors or omissions. This paper is part of NBER's research program in Labor Studies. Any opinions expressed are those of the author and not those of the National Bureau of Economic Research. 
NBER Working Paper \#4142

August 1992

\title{
THE EFFECTS OF HIGH SCHOOL CURRICULUM ON EDUCATION AND LABOR MARKET OUTCOMES
}

\begin{abstract}
There is much public discussion but almost no evidence on the effects of high school curriculum on postsecondary education and on success in the labor market. I use the large variation in curriculum across US high schools to identify the effects on wages and educational attainment of specific courses of study. The main finding is that the return to additional courses in academic subject is small. One cannot account for the value of a year of high school with estimates of the value of the courses taken by the typical student during the year.
\end{abstract}

Joseph G. Altonji

Professor

Department of Economics and Center for Urban Affairs and Policy Research

Northwestern University

Evanston, IL 60208

and NBER 


\section{Introduction and Summary}

Although critics of the curriculum of American high schools often assert that high school programs leave students poorly prepared for the labor market, ${ }^{1}$ there is little hard evidence on the relationship between courses taken in high school and labor market outcomes. ${ }^{2}$ Most research on the relationship between education and wages has examined the effects of years of schooling, and, with much less emphasis, the effects of college major. ${ }^{3} \quad$ A number of recent studies have examined the effects of curriculum on educational achievement. ${ }^{4}$ A few studies have examined the

${ }^{1}$ See, for example, President's Commission on Excellence in Education (1983).

${ }^{2}$ Bishop (1987) and Crouse (1979) provide references to a substantial literature on the relationship between ability measures and academic achievement measures (such as grades) and labor market success, but very few studies have examined directly the link between courses in high school and labor market success. An early exception is Rumberger and Daymont (1984) who examine the effects of credits in academic courses, vocational courses, and "other courses" on the wages, unemployment, and work hours of a sample of out of school 18-22 year olds from NLS Youth. They do not examine specific subjects and look at labor market outcomes shortly after high school. They do find a relationship between total credits and hourly earnings, but the link is very weak among students who graduated from high school. Bishop and Kang (1984) also analyze the curriculum data from NLS Youth.

${ }^{3}$ Willis (1986) provides a recent survey.

${ }^{4}$ See, for example, Alexander and Pallas (1984). This study finds a significant relationship between completing the "New Basics" core requirements recommended by The National Commission on Excellence in Education (1983) and performance on the SAT even when one controls for a measure of pre-high school achievement and aptitude. Interestingly, completing the English component of the New Basics does not affect performance on the English Composition Achievement Test, and completion of the social studies component has no effect on the American History Achievement Test. These findings are consistent with the weak and in many cases negative relationship between semester hours in these areas and wages reported below. However, Alexander and Pallas do find a significant relationship between completing the Math and Science cores (especially Math) and SAT-M. Foreign language has a strong relationship with both the SAT-V and the English Achievement test. The role for foreign language is particularly intriguing in view of the connection reported below between foreign language semester hours and both wages and educational attainment. However, the authors discuss a number of potential biases in their analysis which parallel some of the concerns about omitted variables bias in the present study. See also Meyer's (1992) study. 
effects of high school curriculum on labor market outcomes in the first few years after high school, but little is known about whether the courses a student takes in high school affect wages over the course of a career. ${ }^{5}$ Furthermore, most of the available studies focus on vocational courses or on the effect of track (academic/nonacademic) rather than on the return to the number of courses in specific subjects. The relevance for curriculum design of estimates of the payoff to specific courses is obvious, but such estimates also have implication for the "human capital/screening" debate over why years spent in school have economic value. From the point of view of the human capital interpretations, one would hope that a year's worth of high school courses has value regardless of whether one requires an extra year to complete them. ${ }^{6}$

Why, given the amount of public debate, have so few researchers actually looked at the relationship between labor market success and what students take in high school? Part of the problem has been a lack of data, which in turn reflects a focus in education research on the short term effect of curriculum and teaching methods on aptitude and achievement measures, attitudes, and social behavior rather than longer term economic consequences. Few large scale data sets contain information about (1) high school curriculum, (2) labor market experiences a decade or more after high school, and (3) the large array of variables that are necessary to control for bias arising from the selection process in who takes particular types of courses.

\footnotetext{
${ }^{5}$ Although I focus on wages and postsecondary education, one should keep in mind that primary and secondary schools have many objectives other than to maximize the earnings prospects and the education of students, and these objectives must also be considered in curriculum design.

${ }^{6}$ See Weiss's (1990) discussion of the results of an earlier version of this paper.
} 
A second problem is that there are very serious statistical difficulties in separating the true effects of math, science, foreign language, and industrial arts courses on wage rates from spurious correlations due to common unobserved determinants of both courses and wage rates. In particular, the number of semester hours of high school mathematics, foreign language, and science taken by a particular student is presumably positively correlated with his academic ability and his preferences for postsecondary education. The number of courses are likely to be endogenous in both educational attainment and wage equations given that the available controls for ability and preferences are imperfect.

This paper takes advantage of the availability of data from the 1986 follow up to the National Longitudinal Survey of the High School Class of 1972 (NLS72) to provide the first systematic study of the effects of secondary school curriculum on postsecondary education and on success in the labor market. This data set contains information on the number of semester hours taken by student during 10th-12th grade in a number of subject areas. It also provides information through 1985 on wages. The NLS72 also has measures of family background, parental attitudes toward education, test scores, and a set of high school characteristics. Most importantly, the data set contains several students from each of a large number of high schools (897 high schools in the subsample used in this analysis). The basic idea of the paper is to treat cross-high school variation in curriculum as a natural experiment that may be used to identify the effects on wages and educational attainment of specific courses of study. I estimate by 2 stage least squares using the means for each high school of courses taken in each subject as instrumental variables for the courses chosen by individuals, while controlling for the other characteristics of the individual students and high school variables such as the average characteristics of the students in the high school. 
Unfortunately, differences across high schools in courses taken by the average student in high school do not constitute a clean natural experiment. For example, the average number of math courses in a high school is likely to be positively correlated with the average family background, primary school preparation, ability of the student body and quality of the courses. While I control for average student characteristics and for other high school level variables in the empirical analysis, the controls are almost certainly imperfect. Since there is little prior research or evidence on the effects of curriculum on wages, I also present ordinary least squares estimates of education and wage equations, both with and without high school specific fixed effects. ${ }^{7}$ The use of high school fixed effects permits one to control for all observed and unobserved characteristics of the high school and the community associated with the high school. However, the fixed effects estimates are likely to be particularly susceptible to bias from correlation between individual characteristics that affect course selection and individual characteristics that affect wages or education. I use a simple model of curriculum choice and a descriptive analysis of course taking as the basis for a discussion of methodological issues that must be considered in using nonexperimental data to study the effects of curriculum. $^{8}$

Readers of the paper will see that it raises more questions than it answers. However, the main finding for wage rates is that the return to additional courses in academic subjects is small. Even when one does not control for family background and ability, the instrumental variables

\footnotetext{
7 In the conclusion I briefly mention IV results based on the use of cross-state rather than cross high school variation to identify curriculum effects.

${ }^{8}$ Recent studies of the determinants of curriculum and tracking, with detailed references to the literature, include Lee and Bryck (1988), Vanfossen, Jones and Spade (1987), and Garet and Delaney (1988).
} 
estimates indicate that one more year of science, math, english, social studies, and foreign language would lead to a wage increase of only .3 percent. In other words, the effect of a year equivalent of courses is much smaller than the value of one year in high school. This conclusion is not sensitive to alternative ways of dividing up "credit" for the effect of postsecondary education on wages between high school courses and college, in part because the IV estimates show only a modest effect of academic courses on years of college completed. The OLS estimates, especially when a fixed effect is included for each high school, suggest larger estimates, particularly for mathematics. However, these estimates are likely to be upward biased. In any event, when controls for family background, the OLS, OLS fixed effects, and the IV estimates of the value a year of additional courses are all far below the value of a year of high school.

The main finding for postsecondary education is that IV estimates of the effect of an extra year of academic courses are quite modest even though the OLS-fixed effects estimates show that the number of courses one takes relative to high school classmates has a very strong relationship to postsecondary education.

I provide many reasons to challenge the specific estimates given in the paper, although most suggest that the IV and OLS estimates for academic courses are if anything, overstated. Taken at face value, the results seem more consistent with a "credentialing" or screening view of high school than a human capital view. (See Weiss (1990) for a discussion of earlier draft of this paper against the background of the screening/human capital debate.) But the contribution of the paper is to open up research on the effects of high school curriculum on labor market success rather than to provide point estimates that can be relied upon for policy purposes or to test alternative models of the education-earnings link. 
The paper proceeds as follows. Section 2 discusses of the statistical problems associated with measuring the effects of curriculum on wages or education and the econometric approaches used in the paper. Section 3 discusses the data. Section 4 presents the empirical results. In Section 5 I summarize the main results and present a research agenda.

\section{Issues in Estimating Curriculum Effects}

In section 2.1 I present equations for wage rates and postsecondary education and discuss the interpretation of the coefficients on curriculum. In section 2.2 I describe the instrumental variables estimator and present summary statistics showing that there is considerable variation in curriculum across high schools. In section 2.3 I examine the biases that are likely to be associated with alternative estimation procedures.

\subsection{The Effect of High School Curriculum on Wages and Postsecondary Education}

Let $\mathrm{C}_{\text {ih }}$ be a row vector of measures of high school curriculum taken by person $\mathrm{i}$ from high school $\mathrm{h}$. In the empirical work, $\mathrm{C}_{\mathrm{ih}}$ includes semester hours of math, science, foreign language, commercial courses, industrial arts, social studies, and fine arts. The courses were taken during the 10th, 11th, and 12th grades. Assume that the effect of a change in $\mathrm{C}_{i h}$ on skills that influence labor market labor opportunities is $\alpha_{i h} \Theta_{i h}$, where $\alpha$ is a scaler related to general course quality, aptitude and pre-high school preparation, high school quality, and $\theta$ is a diagonal matrix of coefficients that measure the relative quality of the courses and aptitude and preparation of the student in the various subject areas. The diagonal of $\Theta$ is normalized to sum to 1 . 
Potential earnings in each of a wide set of occupations depends on the skills that the student acquires in high school. Let $\operatorname{lnw}_{\text {ih }}$ denote the maximum wage a person can obtain, and assume that

$$
\operatorname{lnw}_{i h}=C_{i h}\left[\alpha_{i h} \theta_{i h} A_{w}\right]+X_{i h} B_{w}+\rho S_{i h}+e_{w i h}
$$

where $A_{W}$ is a column vector that maps labor market skill acquired in school into wage rates, $X$ is a vector of observed variables that influence $\operatorname{lnw}, S_{\text {ih }}$ is years of postsecondary education, and $e_{\text {wih }}$ is an index of unobserved factors.

I estimate the population average of the vector of partial effects on the $\log$ wage of increasing one of the elements of $\mathrm{C}_{i h}$ by one unit, holding the other elements constant. Denote the vector of these averages as $G_{w^{\prime}}$ where $G_{w}=E\left(\alpha_{i h}{ }^{\theta_{i k}}\right) A_{w}$. One may re-write the above equation as

$$
\operatorname{lnw}_{i h}=C_{i h} G_{w}+X_{i h} B_{w}+\rho S_{i h}+e_{w i h}+C_{i h} g_{w i h} .
$$

The error component $C_{i h} g_{w i h}$ is equal to $C_{i h}\left[\alpha_{i h} \theta_{i k} A_{w}-G_{w}\right]$.

Similarly, suppose that the number of years of postsecondary education that an individual will choose to attempt and will successfully complete given information as of senior year is

$$
s_{i h}=C_{i h} G_{s}+X_{i h} B_{s}+e_{s i h}+C_{i h} g_{s i h}
$$

where $g_{\text {sih }}$ is an unobserved random coefficient and $e_{\text {sih }}$ is an additive error component.

A few points concerning the interpretation of $G_{w}$ and $G_{s}$, their expected sign, and whether one should control for postsecondary education $\left(S_{i h}\right)$ in (1) arise immediately. First, the elements of $G_{w}$ and $G_{s}$ are the 
effects of an additional course that is typical of the quality and content of the courses taken by the Class of 1972 and also abstract from variation across students in unmeasured ability and pre-high school education. ${ }^{9}$ Each element is the partial effect of an increase of one semester hour in a given subject area for a typical student holding hours of other high school subjects constant. One would hope that extra courses in a given subject area, say social studies, do not harm wage rates provided that they do not come at the expense of the number and quality of courses taken in other areas. If one controls for the number of semester hours in other subjects, then one would expect all of the elements of $G_{w}$ to be greater than or equal to 0 .

In practice, I control for a large majority of courses, particularly those taken by students in academic programs. However, study halls and semester hours of certain vocational courses, physical education, drivers education, and home economics are not controlled. ${ }^{10} \mathrm{~A}$ negative bias in the wage or postsecondary education equations could arise if (1) the number

\footnotetext{
${ }^{9}$ The NLS72 provides information on tracking but not on the content of courses other than broad subject area.

${ }^{10}$ The NLS72 asks two sets of questions about curriculum. The first asks schools to report both number of courses and the number of courses broken down by hours per week in the each of eight subject areas examined in the paper during the period after July 1, 1969. The second set of questions (which immediately follows the first) asks schools to "indicate the total number of semester courses this student will have taken in each of the following vocationaltechnical subjects by the time he or she graduates." The sample means of the number of semester hours after July 1, 1969 in the subjects listed in the second set of questions are 3.54 for home economics, 1.23 for agriculture, 11.81 for business, .93 for distributive education, .92 for health occupations and 4.38 for trade occupations. However, it appears that many schools report trade or industrial oriented courses under both industrial arts (question set 1) and trade or industrial occupations (question set 2), and report business/secretarial courses under both commercial (set 1) and business (set 2). (The correlation between industrial arts and trade or industrial occupations is .594. The correlation between commercial and business or commercial is .746.) Consequently, I do not make separate use of this data. The correlation between the sum of the eight courses included in the equations and semester hours in the vocational-technical subjects is -.094 , suggesting only a small bias even if the omitted courses have an important effect on wages or education.
} 
of courses in a particular subject area is negatively related to semester hours in one of the subjects that are not controlled for and (2) the omitted courses have important direct effects on wages or education. However, I doubt that the direct effects on wages are large and the available evidence suggests that the negative correlations are small.

The expected signs for the elements of $G_{s}$ are less clear. Better high school preparation in academic subjects makes college work easier, raising $\mathrm{S}_{\mathrm{ih}}$. However, courses in commercial arts or industrial arts may be expected to have a negative effect on postsecondary academic education if they raise the wage associated with a high school degree relative to the wage associated with a college degree. ${ }^{11}$

A second issue of interpretation is whether or not one should control for years of postsecondary education. If the return $\rho$ exceeds the real interest rate $R$, and $C_{i h}$ influences $S$, then part of the return to $C$ arises because it makes profitable investments in $\mathrm{S}$ easier. Below I discuss estimates in which $\rho$ is set to .04 , which I view as a lower bound on the real interest rate. In this specification $\mathrm{C}$ will get credit for returns to schooling in excess of .04 that are correlated with C. I also experiment with excluding $S$ entirely (constraining $\rho$ to 0 ), but this is inappropriate the opportunity costs of any postsecondary schooling induced by Cih are not taken into account. A second issue is that one might expect interactions between $\mathrm{C}_{\mathrm{ih}}$ and $S$ in the log wage equation. I discuss some limited evidence on this below.

\footnotetext{
${ }^{11}$ When one estimates (1) separately for students who do not attend college and for students who receive college or advanced degrees, one finds that industrial arts has a larger percentage effect on the wages of individuals who do not attend college. One interpretation of the negative coefficient on industrial arts courses in the education equation is that such courses reduce the attractiveness of higher education relative to a high school degree.
} 
OLS estimates of $G_{w}$ in (1) above will be biased if $e_{\text {wih }}$ or the random coefficient vector gwih are correlated with Cih. In the next two sections I discuss alternative approaches to estimation of (1) and (2).

\subsection{Cross High School Variation as a Natural Experiment}

I use the cross high school variation in the curriculum variables to identify the effects of curriculum on $S$ and W. Suppose that all schools provide the same menu of courses of various types, quality, and difficulty to students but differ in the inducements that they provide for students to take particular sets of courses. Assume these differences are unrelated to student characteristics and other unobserved school characteristics. Then variation across high schools in the $\mathrm{C}_{\mathrm{ih}}$ will be unrelated to $\left[g_{w i h}-G_{w}\right] C_{i h}+e_{w i h}$. In the absence of information on school policies and requirements, one could use the high school mean $C_{h}$ of $C_{i h}$ as an instrumental variable for $C_{i h}$ in (1) and (2). One could estimate (1) and (2) by instrumental variables (two stage least squares), with the vector $C_{h}$ and the other variable in the equation serving as instrumental variables for $\mathrm{C}_{\mathrm{ih}}$. Since only $C_{h}$ is excluded from the schooling and wage equations, the IV procedure uses the cross high school variation in courses taken to identify the effects of courses on schooling and wages.

Before discussing potential biases in the IV estimator and in OLS, it is helpful to first ask whether there is much variation across high schools in curriculum. In the top panel of Table $1 \mathrm{I}$ report the average number of semester hours per student in each of eight subject areas and the fraction of variance in semester hours that is across high schools. The mean of total semester hours is 133.33 , which amounts to 4.44 courses meeting 5 days a 
week each semester during 10th, 11th, and 12th grade. ${ }^{12}$ For the average student social studies and English account for $\mathbf{4 3 . 6}$ percent of courses taken in the eight subjects. The table shows that about 26 percent of the variance in science semester hours, foreign language, and math is across high schools. Forty two percent of the variance in social studies and 50 percent of the variance in English is across high schools. The standard deviation of the high school variance component for foreign language is 9.69 , which is almost as large as the sample mean of $\mathbf{1 0 . 8 5}$ for foreign language. When one restricts the sample to academic students, even larger fractions of the total variance are across high schools. Part of the differences across schools in courses taken reflects differences in the students who go to them. But the evidence is certainly consistent with the view that factors that operate at the level of the high school and community are important determinants of curriculum. Garet and Delany's (1988) detailed study of curriculum in four California schools supports this conclusion.

The cross school variance in semester hours reflects variation across schools in both total semester hours and in the fraction of semester hours in the various subjects. Forty-seven percent of the variance in total semester hours is across high schools. Among academic students 54.3 percent of the variance in total semester hours is across schools. The lower panel of Table 1 reports that variation across high schools accounts for 18.3, 24.6, 18.7, and 34.0 percent of the variance in the fractions of semester hours in science, foreign language, math, and English, respectively.

The correlations between the sum of semester hours in the 8 subjects and the fractions of semester hours in the 8 subjects provide further insights into the sources of variation in curriculum. The correlation between

\footnotetext{
${ }^{12}$ Rumberger and Daymont (1984) report information on courses by subject area using data from NLS Youth. However, their sample excludes most individuals who went on to college, and so is not closely comparable to the sample used in the present paper.
} 
fraction science and science semester hours is .8767 . The corresponding correlations are even higher for foreign language semester hours, math, fine arts, commercial, and industrial arts, but are .636 for social studies and only .384 for English. The low numbers for social studies and English may be due in part to the fact that they account for the largest fraction of total semester hours, and in part to the fact that fraction English and fraction social studies are negatively correlated with total semester hours. ${ }^{13}$ In summary, much of the variation in subjects other than English and social studies is due to variation in the allocation among subjects, but variation in total semester hours plays a large role as well.

\subsection{The Relative Bias of the IV Estimator, OLS, and OLS with High School Fixed Effects}

The high school means $C_{h}$ will be valid instruments only to the extent that variation across schools in courses taken is due to variation across schools in objectives and resource constraints that is unrelated to variation across high schools in unobserved factors that influence postsecondary education and wages. Here I present a simple model of

${ }^{13}$ The correlations are -.55 for English and -.40 for social studies. I examined whether these strong negative correlations courses in English and social studies arise in part because nonacademic students take more courses outside of the 8 subjects emphasized in the study than do academic students but take similar numbers of English and social science courses. Using the numbers in Table 1 one may show that the mean of semester hours in subjects other than social studies and English is 70.3 for nonacademic students and 105.4 for academic students. The sum of the means for Social Studies and English are 55.5 for nonacademic students and 57.1 for academic students. However, the mean for the other vocational/ technical courses reported by the schools is 12.9 for academic and 30.9 for nonacademic students, and part of this difference probably reflects an academic/nonacademic differential in industrial arts and commercial arts courses that are also included in the 8 subjects considered here. Taken together, the evidence suggests that nonacademic students take fewer courses than academic students. The figures for 10-12 grade based on NLS72 appear to be loosely consistent with those from a 1980 survey of high school transcripts (Campbell, Orth, and Seitz (1981)), which also shows a large disparity between academic students and general and vocational students in courses in science, math, foreign language, social studies, and English. 
curriculum choice and discuss the major sources of bias. I argue first that the IV, OLS, and OLS with fixed effects estimators are all likely to lead to overestimates of the effects of academic high school courses such as Math, Science and foreign language and second that the bias is likely to be less severe for the IV approach.

$\mathrm{C}_{\mathrm{ih}}$ is likely to be correlated with the additive schooling and wage errors $\mathrm{e}_{\text {sih }}$ and $\mathrm{e}_{\text {wih }}$, respectively, and probably with the random coefficients $\mathrm{g}_{\text {sih }}$ and $\mathrm{g}_{\text {wih }}$ as well. To see this, consider the following simple model of curriculum choice.

A high school student has one unit of time to divide among a set of courses in various subjects and an alternative time use (say leisure) that is valued at $\psi_{\text {ih }}$. All students take enough courses to graduate from high school. The student chooses $\mathrm{C}_{\mathrm{ih}}$ to maximize the utility function

$$
\begin{aligned}
\mathrm{U}_{i h}= & \mathrm{C}_{\mathrm{ih}} \mathrm{a}_{\mathrm{ih}}-.25 \mathrm{C}_{\mathrm{ih}} \mathrm{C}_{\mathrm{ih}}{ }^{\prime}-.25\left(\Sigma \mathrm{C}_{\mathrm{ih}}\right)^{2}+\psi_{\mathrm{ih}}\left(1-\Sigma \mathrm{C}_{\mathrm{ih}}\right) \\
& +\left(\mathrm{q}_{\mathrm{ih}}-\mathrm{r}_{\mathrm{ih}}\right) \mathrm{S}_{\mathrm{ih}}+\operatorname{lnw}_{\mathrm{ih}}
\end{aligned}
$$

where the sum is over the elements of $\mathrm{C}_{\mathrm{ih}}$. This utility function is a reduced form that incorporates the net effect of various rewards and punishments used by family, peers, and schools to induce students to take a particular number and mix of high school courses. That is, the coefficients $a_{i h}$ and $\psi_{i h}$ are influenced by parental preferences, school characteristics and requirements, and the ability, tastes, and pre-high school preparation of the individual. Schools that require a lot of math put pressure on the student to take math courses (perhaps in part by orchestrating peer pressure or pressure from parents.)

Individuals also get direct utility from postsecondary schooling $\mathrm{S}_{\text {ih }}$. The parameter $\mathrm{q}_{\mathrm{ih}}$ reflects parental and peer pressure and the individual's 
tastes for schooling. It may be correlated with $\mathrm{a}_{\mathrm{ih}}$ and $\psi_{\mathrm{ih}}$. The discount rate parameter $\mathrm{r}$ captures the costs of delaying labor market entry. To simplify the presentation consider the case in which there are two course types, $C_{i h}=\left\{C^{m}{ }_{i h}, C^{L}{ }_{i h}\right\}$. Maximizing (3) with respect to $C$ subject to the constraint (1) and the equilibrium relationship (2) between the level of $S$ the individual will choose and the choice of $\mathrm{C}$ leads to the following demand equation for $\mathrm{C}^{\mathrm{m}}$ ih

$$
\begin{aligned}
\mathrm{C}^{\mathrm{m}}= & \left\{\mathrm{a}^{\mathrm{m}}{ }_{i h}-.5 \mathrm{a}^{\mathrm{L}}{ }_{i h}-.5 \psi_{i h}\right. \\
& +\left(\mathrm{q}_{\mathrm{ih}}+\rho-\mathrm{r}_{\mathrm{ih}}\right)\left(\mathrm{G}_{\mathrm{s}}^{\mathrm{m}}-.5 \mathrm{G}_{\mathrm{s}}^{\mathrm{L}}+\mathrm{g}_{\mathrm{sih}}^{\mathrm{m}}-.5 \mathrm{~g}_{\text {sih }}^{\mathrm{L}}\right) \\
& \left.+\left[\mathrm{G}_{\mathrm{w}}^{\mathrm{m}}-.5 \mathrm{G}_{\mathrm{w}}^{\mathrm{L}}+\mathrm{g}_{\text {wih }}^{\mathrm{m}}-.5 \mathrm{~g}_{\text {wih }}^{\mathrm{L}}\right]\right\} / .75 .
\end{aligned}
$$

A similar equation holds for $\mathrm{C}^{\mathrm{L}}$ ih , and the generalization to 3 or more types of courses is straightforward.

OLS estimates of $G_{w}$ in (1) above will be biased if $e_{\text {wih }}$ is correlated with the right hand side of (4) and the analogous equations for other courses. Perhaps students endowed with a high level of general skill in the labor market (high $\mathrm{e}_{\text {wih }}$ ) enjoy academic work (high $\mathbf{a}_{\text {ih }}$ ) more than those with less general skill. OLS estimates of $\mathrm{G}_{\mathrm{w}}$ will also be biased if, as (4) implies, the random coefficient vector $\mathrm{g}_{\text {wih }}$ on $\mathrm{C}_{\mathrm{ih}}$ in the wage equation is related to choice of $\mathrm{C}_{\mathrm{ih}}$. This would be the case if students, as the result of their own preferences or pressure from school officials and parents, tailor their courses to the ones that have the highest payoff in the labor market given their personal characteristics. Students with a comparative advantage in certain subject areas might be expected to take more of that subject and less of another. Students with an absolute advantage in all subjects (a high 
$\alpha_{i h}$ ) might be expected to take more courses (and have fewer study halls, driver education, etc.) and to take more difficult courses.

I now discuss each of the major sources of bias.

1. Unobserved differences in pre-high school ability and achievement.

Table A-2 reports correlation coefficients and regression coefficients from a series of univariate regressions (with intercept) of the curriculum variables, education, and wages against a student's own assessment of his ability (BQ28), the student's view of his teacher's expectations for him (SQ149), a battery of achievement and aptitude tests, and high school grades. The results confirm many previous studies that find that ability and achievement are positively correlated with both education and wage rates. ${ }^{14}$ The ability and achievement measures are also positively correlated with semester hours of math, science, and foreign language and are also higher for students in the academic track within a high school. ${ }^{15}$ They are negatively correlated with semester hours of commercial arts and industrial arts.

The correlations suggest that selection in who takes math, science and foreign language is likely to lead to a positive bias in estimates of the effects of these variables on wages and education. For similar reasons, I would expect a downward bias in estimates of the effects of industrial arts, commercial arts, and perhaps fine arts and social studies. ${ }^{16}$ Variation in unmeasured ability and preparation across high schools probably poses less of a problem for the IV estimator than the OLS fixed effects estimator, in

\footnotetext{
${ }^{14}$ The negative values for BQ28, SQ149 and grades (IMPTAVER) simply reflect the fact that small values of these variables correspond to high ability and high grades.

${ }^{15}$ I discuss the possibility that the correlations arise because curriculum alters test scores below.

${ }^{16}$ More able and better prepared students are likely to do better in academic courses such as math, science and foreign language. Furthermore, they are more likely to be interested in attending college, and as a result, be more interested in college preparatory courses and less interested in commercial courses or industrial arts.
} 
part because high school averages of aptitude and achievement measures are likely to be more reliable than the measures for a given individual.

2 Unmeasured differences in parental characteristics. The simple correlations in Table A-2 indicate that students with family background characteristics that are favorable for education and wages take more semester hours of math, science and foreign language and fewer commercial and industrial arts courses. Parents who push their children to obtain high levels of education (induce a high $\mathrm{q}_{\mathrm{ih}}$ in the utility function (4)) may also push them to take math, English, science and foreign language in high school and discourage industrial arts or commercial courses (influence the value of the $a_{i h}$ vector). This is likely to lead to a positive bias in estimates of the effects of math, science, and foreign language coefficients and a negative bias in industrial arts and commercial arts. It is not clear whether the bias will be more severe for the within high school analysis than for the IV analysis.

\section{Unobsenved differences across high schools in emphasis on} academic courses. High school differences in emphasis on academic courses will not have a large effect on the within high school analysis, since high school variables are held constant. These differences may lead to upward bias in the IV estimates of the effects of academic courses on education but probably have little effect on the wage equation, on the assumption that high school placement activities influence student interest in and access to college but do not have much of a direct effect on employment opportunities.

4a. Unobserved differences among students from the same high school in the difficulty and quality of instruction of cousses in each subject area. High school math can range from calculus to courses that teach basic arithmetic. Similar problems of heterogeneity exist for English, Social Studies, and Science. (See Adelman (1983).) There is evidence that the 
number of math, science, and foreign language courses taken is positively related to the level of the courses taken. ${ }^{17}$ Assuming that more advanced courses are worth more for postsecondary education and wages, this implies a positive correlation between $\mathrm{C}_{i h}$ and the random coefficients $\mathrm{g}_{\mathrm{sih}}$ and $\mathrm{g}_{\text {wih }}$. The implication is that the within high school estimates of the coefficients on the number of math, science, and English courses taken will be biased upward by a positive association between the number of courses taken and the level and quality of the courses. I perform separate analyses for students in the academic and nonacademic program under the assumption that course content and instruction quality are homogenous within track. ${ }^{18,19}$

\section{Unobserved differences across high schools in the content and} quality of instruction of cousses in each subject area. There is evidence in the NLS72 of a positive association between the number of foreign language, math, science, and English courses taken by the average student in a high school and the level and quality of those courses. ${ }^{20}$ This would lead to an

\footnotetext{
${ }^{17}$ In the NLS72 data there is a positive correlation between the number of semester hours of Math, Science, and foreign language and the track level of the students. This correlation holds for students in the academic program as well as for all students. Heyns (1974) finds that more able teachers and better classroom equipment and materials are used in higher level courses.

${ }^{18}$ It is not clear, however, that this will eliminate the problem. Courses within a program are probably more homogenous than courses in the high school at large, but the variance of semester hours in each subject area is also smaller within a program than in the high school as a whole.

${ }^{19}$ Only 5.2 percent of the sample received remedial instruction in reading and 3.1 percent received remedial instruction in math. Remedial math instruction has a weak negative relation to math semester hours. Remedial reading instruction has a 0 correlation with semester hours in English. Evidently, formal remedial courses have little to do with the variation in courses taken in these subjects.

${ }^{20}$ Science and foreign language are negatively correlated with the teacher turnover rate and positively correlated with the fraction of teachers with advanced degrees.
} 
upward bias in the effect of these variables on education and wages in the IV analysis.

5. Self selection and wealth maximization. The wealth maximization model of education choice holds that students choose the level and type of education that has the highest payoff given their abilities and financial constraints. Presumably, one goal of guidance counselling is to direct students toward courses that will be most valuable for the particular student. In the model above unobserved differences across students in aptitude, prehigh school preparation, and interest in particular subjects are reflected in the absolute advantage parameter $\alpha_{i h}$ and the comparative advantage parameter $\Theta_{i h}$ and lead to differences in the effect that particular courses have on wages. One might suspect that the estimated effect on education and wages of courses actually taken by students is likely to be larger than the wage effect that the same set of courses would have for students who chose other sets of courses. ${ }^{21}$ However, the bias from self selection appears to depend on a number of factors, including the extent to which there is comparative advantage versus absolute advantage, and on the source of the variation in curriculum.

To provide insight into the likely bias from comparative advantage, I analyzed a version of the above model containing only two course types, $m$ and $L$, with the preference parameter $a^{\mathbf{m}}$ ih equal to $a^{L}{ }_{\text {ih }}$, the utility parameter $\psi$ and the absolute advantage variable $\alpha$ equal to constants, and $A_{w}$ equal to an identity matrix. I also assumed $q_{i h}=0$ and that discount rate

\footnotetext{
${ }^{21}$ For an analysis of the effects of self-selection on estimates of the return to higher education see Willis and Rosen (1979) and the general discussion in Willis (1986). I do not know of any studies that adapt their methods to the choice of high school curriculum. Since the choices of students appear to be heavily influenced by parents and schools and by factors that may not be strongly related to future wages or success in postsecondary school, it will not be easy to do so without major advances in the modelling of the objective function of high school students and the constraints schools and parents place on their choices.
} 
$\mathbf{r}_{\text {ih }}$ equals the education slope $\rho$, in which case postsecondary education does not influence course selection. In this special case, one can show that the estimates of $G^{m}$ and $G^{L}{ }_{w}$ are unbiased provided that the distribution of $\theta^{m}$ ih (and therefore $\theta^{L}{ }_{\text {ih }}$ ) is symmetric and that the estimate of the sum of the coefficients are unbiased regardless of the distribution of $\theta^{m}$ ih ${ }^{22}$ The estimate of $G^{m}{ }_{w}\left(G^{L}{ }_{w}\right)$ is biased up (down) if the distribution of $\theta^{m}{ }_{\text {ih }}$ is skewed to the right.

The IV estimates will be unbiased if high schools differ in the total number of courses they require but have student bodies with the same distribution of $\Theta_{i h}{ }^{23}$ On the other hand, bias in the IV estimates is possible to the extent that differences across high schools in course taking result from differences in the mix of students rather than differences in requirements.

The case of absolute advantage (variation in $\alpha$ ) is similar to the problem of unobserved differences in pre-high school ability and achievement discussed earlier. In this case, the within high school estimates are likely to overstate the effects of courses. The IV estimates will as well, although the upward bias is probably reduced by the use of high school averages of aptitude and achievement measures as control variables.

In summary, the effects of self selection in the presence of differences across students in comparative advantage in particular courses may lead to biases in the within high school estimates, but the sign is uncertain. Self selection with comparative advantage will have less of an effect on the IV estimates. Absolute advantage is likely to lead to an upward bias.

\footnotetext{
${ }^{22}$ Here I am abstracting from the other sources of biases discussed earlier.

${ }^{23}$ In the model above schools may induce higher values of $a_{i h}^{m}$ and $a_{i h}^{L}$
} 
6. Choice of control variables. The NLS72 measures of parents's aspirations and student achievement and ability are measured during the Spring of 12 th grade. Both may be affected by courses in high school. The problem may be particularly severe in the education equation for the dummy variables FWCOLL2 (father wants college) and MWCOLL2 (mother wants college), and I exclude these variables from the equations reported in the Tables 2 and 3 below. ${ }^{24}$

A similar issue arises for test scores, because scores in math, reading, and vocabulary, the students perception of his own ability (BQ28) and his perception of how teachers rank him (SQ149) may be influenced by curriculum. In this case, controlling for the ability and achievement measures may bias downward the estimates of the effects of academic courses. On the other hand, failure to control for pre-high school ability differences may lead to biases in the other direction. Furthermore, the fact that foreign language and mathematics have very similar correlations with the battery of aptitude and achievement measures suggests that general cognitive ability has an important influence on both the verbal and the mathematics tests. (See Table A-2) Previous studies that contain information on 9 th grade and 12th grade test scores suggest that 12th grade test scores are dominated by the effects of prior ability and achievement rather than by experiences during high school. ${ }^{25}$ I discuss estimates with and without controls for ability and achievement.

${ }^{24}$ These variables have a strong relationship to years of education (see Table A-2). However, both the student's perception of his parents' actual preferences, and his parents' preferences may be influenced by whether or not the student will be attending college. In this circumstance, it would be incorrect to control for parents' aspirations.

${ }^{25}$ See, for example, Alexander and Pallas (1984), who find effects of curriculum on SAT Math and SAT Verbal tests administered in 12th grade but also note that curriculum has little explanatory power for SAT scores once one controls for 9 th grade tests. 
7. Bias in a multivariate context. Most of the discussion suggests positive bias in the coefficients on Math, Science, and Foreign Language, and negative bias for industrial arts and commercial, with uncertain bias for English, social studies, and fine arts. However, in most cases the argument is based upon consideration of simple correlations between a particular curriculum variable and omitted factors that affect wages and education. Eight curriculum variables are included in the models, and the curriculum variables are correlated. An overestimate of the coefficient in one subject area, say foreign language, could lead to a net downward bias in the coefficient on a subject that has a positive covariance with foreign language, say science. One would still expect the sum of the coefficients on foreign language, science, and math to be overestimated. Below I discuss estimates of the coefficients on foreign language, science, and math when they are constrained to be equal in magnitude, I also discuss experiments in which the coefficients on foreign language, and in some cases, English and social studies are set to specific values prior to estimation. ${ }^{26}$ Finally, I emphasize the estimates of the combined effect of sets of courses.

\section{Data}

\subsection{Sample Selection Criteria}

The NLS72 is a Department of Education survey of individuals who were high school seniors during the 1971-1972 academic year. The initial interview was conducted during the Spring of 1972, with followup surveys in 1973, 1974, 1976, and 1979. A subsample was resurveyed in 1986. The sample means used as instruments and control variables in the IV procedure are calculated from the subset of the 22,652 persons in the base year survey

\footnotetext{
${ }^{26}$ Dropping a subset of curriculum variables from the model will lead to omitted variables bias in the coefficients on the curriculum variables that remain in the equation.
} 
who have valid data on a particular variable, regardless of whether they remained in the survey. ${ }^{27}$ A subsample of 10306 met various sample selection criteria and had valid data on the variables used in the education analysis. ${ }^{28}$

${ }^{27} \mathrm{I}$ also experimented with excluding the vector $\mathrm{C}_{\mathrm{ih}}$ of courses taken by person $\mathrm{i}$ from the computation of $C_{h}$ because the discussion above implies that $C_{i h}$ is likely to be correlated with $\mathrm{e}_{\text {wih }}, \mathrm{g}_{\mathrm{wih}}, \mathrm{g}_{\mathrm{sih}}$, and $\mathrm{e}_{\mathrm{sih}}$. Using these alternative instruments in place of the mean values of $\mathrm{C}_{\mathrm{ih}}$ computed over all students leads a modest reduction in the IV estimates of the effects of the academic courses on wages and education.

${ }^{28}$ The NLS72 contains data on 22,652 people, 12,841 of whom were re-surveyed in 1986. 1 restrict the sample first to the 16,683 individuals from the 1069 schools that participated in the base year survey, then to the 15,680 for whom high school test information is available, and then to the 12980 individuals who were surveyed in each of the 1973, 1974, 1976 and 1979 followups. Information from the 1986 followup was then added, and only those 7358 persons who were in the earlier 12980 sample were included. The sample of 12,890 from the 1972 1979 surveys forms the basis for the analysis of education outcomes. Of these 10306 had valid data on the variables used in the analysis, which is about 61.8 percent of students in the base year sample and 65 percent of students in the base year for whom test data are available. The fact that sample is limited to persons who answered the first four surveys may lead to selection bias. Attrition rates are higher for persons with disadvantaged backgrounds. The mean for LOWSES for the full sample and for the sample used in the education equations are .285 and .256 , respectively. The corresponding means of BLACK are .1377 and .0993 . The values for CFAED (father's education) are 12.43 and 12.60. Persons who did not attend post secondary school constitute 21.38 percent of the sample of persons for whom a composite measure of educational attainment by 1979 is available and 22.68 percent of the present sample. These numbers suggest that the issue of selection is probably most serious for the black-white comparisons, which are not emphasized in this study. The table below presents the means of the curriculum variables for the 10306 persons used in the education analysis and the base year:

$\begin{array}{llcccl} & \text { SCIENCE } & \text { FOR.LANG. } & \text { SOC.ST } & \text { ENGL. } & \\ \text { Education sample } & 18.73 & 10.84 & 26.23 & 30.00 & \\ \text { Base year sample } & 17.99 & 9.67 & 26.09 & 29.95 & \\ & & & & & \\ \text { Education sample } & 19.18 & \text { IND.ARTS } & \text { COMMERC } & \text { FINE } & \text { HSACAD } \\ \text { Base year sample } & 18.55 & 6.34 & 14.05 & 8.69 & .452 \\ \end{array}$

From the means, it is clear that the attrition rate is higher for nonacademic students, and this is reflected in the differences in the mean values for courses such as foreign language and industrial arts. The higher attrition rate for nonacademic students may be related in part to the higher attrition rate for blacks, who are disproportionately represented in general and vocational tracks. To the extent that unobserved characteristics that are uncorrelated with high school curriculum and negatively related to post secondary education and to labor market success are also positively correlated with attrition, then attrition is likely to be a source of negative bias in estimates of the effects of academic courses on education and wages. I make no attempt to quantify this bias. The IV estimates may also be affected despite the fact that $C_{h}$ is computed using the base year sample. I omit the argument to save space. 
The cross section-time series of observations for each individual used in the wage analysis was created using information on earnings divided by hours for 1977, 1978, and 1979, and information on the wage at the beginning and end of each job held between 1980 and 1986 up to a maximum of the four most recent jobs. ${ }^{29}$ The wage sample contains 38,595 observations on 9239 individuals from 897 high schools. ${ }^{30}$ Descriptive statistics are provided in Table A.1.

\subsection{Key Variable Definitions}

The variable YEARSACD measures years of education as of the 1979 survey. ${ }^{31} \quad$ A set of mutually exclusive dummy variables for postsecondary education are defined in Table A.1 and used in the wage equation (VOC, SOCOL14, SOCOL15, COLLEGE and ADVANCED). As noted above, it is important to control for postsecondary education, because otherwise one might give high school curriculum credit for wage increases

${ }^{29}$ An observation for 1977 is included if (1) the individual was not a full time student in October 1976 nor October 1977, (2) hours worked in 1977 was greater than 1,040, and (3) the 1977 real wage was between \$.50 and \$75 in 1967 dollars. Observations for 1978 and 1979 were included if they met the corresponding three criteria for 1978 and 1979 respectively. Data for begin and end job dates (1980-86) were included if (1) the hours worked in the appropriate year was greater that 1040 , and (2) if the real wage was between $\$ .50$ and $\$ 75$ in 1967 dollars.

${ }^{30}$ The corresponding values for academic sample are 18,653 observations on 4292 individuals from 858 high schools. For the nonacademic sample, the values are 19942 observations on 4947 individuals from 865 high schools. For the pooled sample the number of observations per person in the wage sample is 4.177 with a standard deviation of 2.34 and a range from 1 to 11 . Fifty-two percent of the wage observations come from 1977, 1978, or 1979,21 percent come from 1985 or 1986 , and 27 percent come from 1980, 1981, 1982, 1983 , or 1984.

${ }^{31}$ It is coded as follows: for high school graduates, 1 for persons with less than 2 years of college, 2 for persons with two or more years of college but no BA or BS, 4 for college graduates, 6 for masters, and 8 for Ph.Ds.I use education as of 1979 rather than education as of 1986 because not all students were included in the 1986 followup. 
that result from investments of time and money in postsecondary education. $^{32}$ However, I do not control for field of college or advanced degree, so the curriculum coefficients will reflect any association between high school semester hours and the rate of return to college or to advanced degrees. This is appropriate if the cost of a degree is independent of field. I use the dummies rather than YEARSACD because the results suggest that the link between postsecondary education and wages is nonlinear but I also experiment with alternative specifications. ${ }^{33}$

The measures of semester hours refer to courses taken between July 1, 1969 and the date the student will graduate, and so refer to 10th, 11th, and 12th grade for most students. The information was provided by the high schools. The semester hour variables were computed by taking the sum of the semester courses in each subject area, with each course weighted by the number of hours per week that it met (from 1 to 6$) \cdot{ }^{34}$ The subjects are

\footnotetext{
${ }^{32}$ I also control for labor market experience PEXP10, which is a count of the number of years the person worked more than 1,000 hours between 1973 and the present, excluding years prior to 1980 in which the person was a full time student.

${ }^{33}$ Although the link between years of postsecondary education and wages is nonlinear, with most of the return associated with receiving a college degree or an advanced degree, it is not clear whether one should allow for the nonlinearity in estimation. The analysis in Altonji (1991) indicates that to the extent that courses raise the probability that someone who starts college receives a degree, they raise the rate of return to education. Given the focus of the present study on the total effect of courses on wages, with other investments in human capital held constant, this effect on the rate of return probably should be attributed to courses. However, in the case of OLS with controls for family background, geographical variables, and aptitude and achievement, replacing the categorical education variables with YEARSACD and YEARSVOC has only a small effect of the coefficients on the semester hour variables. The OLS coefficients on YEARSACD ranges from .055 to .07 depending on the controls. In the IV case with controls for family background and geographical variation, the use of YEARSACD and YEARSVOC makes very little difference. I discuss related experiments in below.
}

${ }^{34}$ In about 20 percent of the cases the high school reported the number of semester courses taken by the student but did not break down the courses by frequency of class meetings. For students for whom both semester hours and semesters are available, 1 regressed semester hours in a given subject against a constant and a fourth order polynomial in semester courses. I then used the estimated regression to impute semester hours for students who had positive semester courses and for whom it was not possible to compute semester hours 
industrial arts, commercial, fine arts, science, math, social studies, English, and foreign language. ${ }^{35}$ The variable HSACAD is 1 if the school reported that the student's course of study was academic, college preparatory and 0 if course of study was general or vocational. ${ }^{36}$

\section{Empirical Results}

\subsection{The Effects of Curriculum on Wage Rates}

Table 2 reports OLS estimates with and without controls for high school of the effects of curriculum on the $\log$ of the real average hourly wage. ${ }^{37}$ The OLS, fixed effects, and IV standard errors allow for arbitrary high school specific patterns of correlation and heteroscedasticity among the errors that correspond to individuals from a given high school. They assume independence across high schools. ${ }^{38}$ The estimates in Table 2 refer to the

directly. A similar procedure was used impute semester hours in the vocational-technical subjects discussed in footnote 10 .

${ }^{35}$ School specific measurement error might arise if some schools made systematic errors in reporting semester hours or differ in classification schemes by subject. Also, there is some variation across schools in the length of a period. One might expect systematic errors at the school level to lead to a downward bias in the IV estimates relative to the other procedures. However, exclusion of schools for which semester hours reported seemed implausibly low had little effect on the results. Excluding the small number of schools who reported standard class periods of less than $\mathbf{4 0}$ minutes or more than $\mathbf{7 0}$ minutes and adding cubics in period length to both the instrumental variables list and the wage equation did not make much difference. The differences across schools in period length probably means that Table 1 overstates school differences in course time by a small amount.

${ }^{36}$ In the base year sample 43 percent of the students in general-vocational category were in vocational programs. Of the vocational students, 46 percent were in business-commercial programs and 34 percent were in trade-industrial programs. I work with the combined categories because of sample size limitations and to keep the analysis and presentation manageable.

${ }^{37}$ Simple regression coefficients and correlation coefficients relating the eight course variables to the log wage and to YEARSACD are shown in Table A-2.

${ }^{38}$ Unfortunately, the corrected standard errors are much larger than the uncorrected standard errors. 
combined sample of academic and nonacademic students. Estimates for the subsamples are in Tables B-1 to B-6 and are briefly discussed in the text.9

In each column $I$ indicate whether controls for region, city size, and proximity to college, controls for family background, and controls for aptitude and achievement have been included. Race, hispanic background, sex, experience, and the year are included in all equations. When instrumental variables are used I include school averages of all individual specific variables control variables among both the instruments and the controls. The semester hour variables have been multiplied by 10 , so the coefficients represent the effect of a one year course that meets 5 days a week on the log wage. Given the log specification, the coefficient times 100 is approximately equal to the percentage change in the wage associated with an extra year of the particular subject. I first discuss the results for each of the eight course variables and then turn to the effects of combinations of courses, which are more precisely estimated.

Science. The simple regression coefficient of .054 relating a year of science to wages is very large, but the multivariate OLS results indicate a small, positive effect of .0030 that falls to 0 when family background and test scores are controlled for. The OLS-fixed effects estimates suggest larger effects, which is to be expected. However, the IV estimates, while imprecise, indicate that a year of science has little effect on wages.

The OLS estimates for the academic sample are very similar to those for the combined sample and are actually negative for the nonacademic sample. The estimates are much larger when high school fixed effects are included, ranging from .0183 to .0140 . However, the IV estimates for the academic sample are actually negative. The OLS estimates for the

\footnotetext{
${ }^{39}$ The standard errors reported in these tables have not been corrected and are seriously understated.
} 
nonacademic sample point to a weak negative relationship between science semester hours and wages. However, the IV estimates range from .0080 to .0111 with an corrected standard error of about .014 , and so are consistent with a substantial positive effect of science on wages, although the evidence is weak.

Mathematics. The OLS estimate when one controls only for region, city size, and distance of the high school from a college is that a year of math raises wages by 1.9 percent (Table $2, \mathrm{col} 5$ ). This is large effect given that the value of a full year of postsecondary education is about 7 percent. However, when one controls for background, this estimate falls to 1.8 percent, and the addition of controls for aptitude and achievement reduces the estimated effect to .6 percent in column (7). The estimates with high school dummies are substantially larger but are probably biased upward for reasons discussed earlier. The IV estimates suggest a less important role for Math courses, although they are imprecise. When background and ability controls are omitted, the IV estimate is -.0003 with a corrected standard error of .015 . However, when one controls for background the estimate falls to -.0074 , and when ability controls are added the estimate is -.0120 . The IV estimates provide little evidence that Math courses have more than a modest direct effect on wages. However, it is also the case the IV estimates are highly imprecise, and one cannot rule out a substantial positive effect.

Foreign Language. Foreign language is the third subject area in which academic students take significantly more courses than nonacademic students. The OLS results for the combined sample show an effect ranging from .0122 in column 1 to .009 when one controls for family background, aptitude and achievement, and school characteristics (not shown). These effects are substantial. (They are smaller for the academic sample (.0041 to 
.0029) and are larger for the nonacademic sample.) For the combined sample and the two subsamples, the coefficients fall when one controls for the high school, which is the opposite of what one would expect given abundant evidence in Table A-2 that semesters of foreign language are positively correlated with aptitude and achievement and with favorable family background characteristics. ${ }^{40}$ It is possible that this is due to an interaction among the biases in the math, science, and foreign language variables. The coefficients on math and science increase when one controls for the high school. I return to this issue below.

When one turns to the IV estimates, one finds a large positive effect of foreign language on wages in the combined sample and in the academic and nonacademic samples. In the combined sample when one controls for ability and background one obtains a coefficient of .023 . This implies that two years of foreign language would raise wages by 4.71 percent. $^{41}$

In summary, there is evidence that foreign language matters for wages. In contrast to science, mathematics, and verbal skills, it is difficult to think of direct links between skill in foreign language and worker productivity in the US economy during the sample period. The discussion of bias above suggests that omitted variables bias (and/or sampling error) are partly responsible for the large coefficients on foreign language. However, the courses may play a role in the development of general cognitive skills and communication skills. Another possibility mentioned earlier is that foreign language may be positively correlated with the level and quality of other academic courses (e.g., math) that do directly affect

\footnotetext{
${ }^{40}$ Compare columns 5 and 7 to 8 and 9.

${ }^{41}$ The coefficient estimate does decline to .015 when one add controls for whether the student reported that his father and his mother wanted him to attend college and controls for additional high school variables. (Not reported.)
} 
labor productivity. Interestingly, when one splits the sample by education level, one finds a much stronger relationship between foreign language and wages for those who did not attend college than for those who did, although the instrumental variables estimate for the college sample also suggest a large effect of foreign language on wages. (Results not reported.) This is consistent with the notion that foreign language in high school contributes to general skill development and may substitute for liberal arts courses in. college, or that variation across schools in the quantity of foreign language offered and required, particularly to nonacademic students, is related to other characteristics that matter for wages. As we shall see, the instrumental variables estimates suggest a modest link between foreign language and educational attainment.

English and Social Studies. The coefficient relating social studies to wages is negative for all specifications, estimation procedures, and subsamples. Controlling for background characteristics makes little differences, although the coefficient is generally smaller in absolute value when one controls for background and aptitude and ability and than when one does not. Taken at face value, these results suggest that the mix of social studies courses offered during the late 1960's and early 1970's were of little value in the labor market. A simple interpretation of the findings is that negative selection in the type of students within a given school who concentrate in social studies and in the type of schools that offer large numbers of social studies courses overwhelms a small positive effect that the courses may have on marketable skills.

The results for English also suggest that additional semester hours have little effect on wages. The OLS coefficients are all negative for the combined, academic, and nonacademic samples. The IV estimates are also generally negative, but are not statistically significant. The coefficients tend 
to become less negative in absolute value when one adds additional controls to the equation. The ratio of semester hours of English relative to semester hours of foreign language and math is negatively correlated with the aptitude and achievement measures and positively correlated with favorable family background characteristics. Adding controls for these characteristics increases the English coefficient and reduces the foreign language and math coefficients.

Industrial Arts. The coefficient on industrial arts is typically about .013 for both OLS and OLS with controls for each high school. The standard error is .004 . The IV estimates are typically smaller, but the point estimate is .011 when controls for family background, aptitude and achievement, FWCOLL, MWCOLL, and an additional set of high school variables. (Not shown). However, the standard error is .011 and the IV coefficients become very sensitive to the control variables when one divides the sample into academic and nonacademic students. ${ }^{42}$

Commercial arts has a zero coefficient for the combined sample in Table 6. The results are not very sensitive to choice of control variables or to the inclusion of dummy variables for each high school. However, the IV estimates show a modest return to commercial courses, and the return is especially large for students in academic programs. It is interesting to note that commercial arts and industrial arts are negatively related to most of the

\footnotetext{
${ }^{42}$ The OLS results for the sample of student who did not go on to college suggest a positive effect between .0116 and .0123 , although the IV estimates are close to 0 (with large standard errors). The OLS estimates for college sample are about .006 but with a large standard error, and the IV estimates are negative but poorly determined. Thus, the results on the subsamples are generally consistent with the view that industrial arts courses are most valuable for those who do not go on to college. On the other hand, the results for college and noncollege going samples contain many anomalies and probably should not be taken to seriously.
} 
ability and background measures. Consequently, the positive coefficients are obtained in spite of negative selection bias. ${ }^{43}$

Fine Arts. If jobs that utilize training in the fine arts have desirable nonpecuniary attributes but pay poorly, and if students who take large numbers of fine arts courses tend to take such jobs, then one would expect to obtain a negative wage coefficient on fine arts even if such courses have no effect on general labor market productivity. Most of the coefficients are negative.

Wage Effects of Cousse Combinations. It is interesting to examine the effects of increases in combinations of courses, particularly given that the IV estimates of the coefficients on the individual courses are somewhat imprecise. Beneath each column in Table 2 I report the effect on the wage of 10 more semester hours ( 1 year, 5 days a week) of math, science, and foreign language. The OLS estimate is $.035(.006)$ without background controls and $.033(.006)$ with the controls. This estimate falls to $.016(.007)$ when controls for aptitude and achievement are added. The IV estimate is $.031(.013)$ without background controls and $.017(.012)$ when one controls for family background. The IV estimates indicate that one more year in each of the 5 academic subjects is associated with a wage reduction of -.009 (.013) when one controls for family background (column 2). The corresponding OLS estimates are very similar. The OLS-fixed effects estimate is .025 when detailed controls are excluded (column 8) and .005 when family background and ability are controlled for. The table also reports estimates of the combined effect on the wage of increasing the 5

\footnotetext{
${ }^{43}$ Given that commercial arts are taken primarily by women and industrial arts by men, I re-estimated the models separately on male and female samples. The point estimates of the return to commercial arts are larger for males than females, but the difference is not statistically significant. The estimate of the return to industrial arts is very imprecise for females.
} 
academic courses by the average number of semester hours taken per year in each subject. The combined effects are negative and in some cases statistically significant. The combined effect of the average number of courses per year in each of the 8 subjects is also negative.

In summary, I cannot account for the value of a year of high school with the value of courses taken on the intensive margin. This conclusion is robust to the choice of estimation method and control variables. It is also robust to a number of additional sensitivity checks, to which I now turn.

Testing for Interactions among the Biases in the Curriculum Variables.

If the large IV coefficient on foreign language is due to estimation bias, then the coefficients on Science and Math may be biased downward to some extent, since these courses have a positive covariance with foreign language. I performed several experiments to examine whether the IV coefficients for math, science, and some of the other subjects are very sensitive to the estimated value for foreign language. For the specification in column 2 of Table 2, which is for the combined sample and includes controls for family background but not for aptitude and achievement, the coefficient on foreign language is .023 . When the foreign language coefficient is set to .005 prior to estimation, the coefficient on science rises from .001 to .004 . The math coefficient increases from -.007 to -.001 . The other coefficients (in particular, social science and English ) are not affected very much by variation in the coefficient on foreign language. When one estimates the model with the restriction that math, science, and foreign language have equal coefficients, one obtains an estimate of .005 when the aptitude and achievement controls are excluded. The restricted equation implies that a reduction in social science and English courses accompanied by an increase in math, science and foreign language would substantially increase wages. 
When one restricts all of the coefficients to be the same and excludes aptitude and achievement controls, the point estimate is -.002 . The fact that total semester hours has a weak negative effect on wages suggests either that there are strong diminishing returns to additional courses or that the large return to a year of high school is not closely connected to what students actually do while in school. Restricting the coefficients on English and social science to be 0 while setting the foreign language coefficient to .005 leads to math and science coefficients that are near 0 .

Treatment of Pastsecondary education. I have also estimated models with years of postsecondary academic and vocational education entered in linear form with the coefficient restricted to a low estimate (.04) of the private discount rate, with and without the restrictions on foreign language, and with and without restricting the coefficients on English and social studies to 0 . When all of the restrictions are imposed, and one controls for family background, the return to an extra year of science is .0047 and the return to an extra year of math is -.009 . The combined effect of an additional year of Math, the science, and foreign language is only .001. When only the postsecondary education coefficients are restricted and one controls for family background, the effect of foreign language increases to .028 and the coefficient on science increases to .0022 . However, the coefficient on math remains negative (-.0056) and the coefficients on English and Social studies become more negative. The combined effect of an extra year of math, science and foreign language is .025 , but the combined effect of an extra year of each of 5 academic subjects is $-.005 .^{44}$ All of the results are qualitatively consistent with the results for course combinations

\footnotetext{
${ }^{44}$ When the coefficients on YEARSACD AND YEARSVOC are restricted to $0(\rho=0)$ and family background is controlled for, the sum of the coefficients on the 5 academic courses is only .003 . The coefficients on science, foreign language, and math are $.002, .034$, and .0001 , respectively.
} 
in column 2 of Table 2. There is little evidence that interactions among the biases in the curriculum variables or that overcontrolling for postsecondary education variables underlie the poor performance of the academic variables, particularly math and science. ${ }^{45}$

The Effects of Curriculum on Wage Growth Rates. I have also conducted a limited analysis of the effects of curriculum and wage growth rates. $^{46}$ I regressed the change in the wage rate against the course variables, the time interval DTIME between wage observations (which is a proxy for the change in experience), and change in the square of experience, and interactions between DTIME and various sets of control variables, including YEARSACD, YEARSVOC, race, hispanic background, and sex. The results indicate that a year of science raises the growth rate per year by .29 percent with a $t$ value of 2.8 . The corresponding number for foreign language is .21 percent with a $t$-value of 2.37 . For math, the effect is .1 percent and is not significantly different from 0. (English, Social Studies, and industrial arts, and fine arts typically have small negative coefficients, and commercial has a small positive coefficient. Controlling for test scores has little effect on the science coefficient, but reduces the coefficient on foreign language and on math to essentially 0 . It is interesting to note that

\footnotetext{
45 I estimated separate models for men and women. The point estimates suggest a substantial positive effect of industrial arts and especially foreign language for both groups. The coefficients on English and Social Studies are comparable to the IV estimates in Table 2 for both groups. A year of Math raises wages by 1.4 percent for the men when family background is controlled for, but science has little effect. For women science has a positive effect but Math does not. These estimates are not very imprecise.

${ }^{46}$ If unobserved family background characteristics or school characteristics affect wage growth rates as well as curriculum choice, then some of the potential biases that affect the level equations might affect the growth equations even though fixed individual and school characteristics do not appear in the growth equation. However, there is not enough cross school variation in curriculum to permit adaptation of the IV procedure to the growth equations.
} 
the ability measures, especially Math, have a strong positive relationship to wage growth, and so the weak results for math courses are puzzling.

The main point to be made about the wage growth results is that there is some evidence that science may have a delayed return in the labor market even if the effect of science on the level of wages in the first 10 years in the labor market is small.

It should also be noted the estimated effect of the academic courses on wage growth is larger if one does not control for years of education in the wage growth equations. This leads to a potentially important caveat. Recent work by Murphy and Welch (1989) and others suggests that there has been a dramatic increase in the returns to education since the early 1980's. The majority of the observations on wages rates used in the present study are from the late 1970's or early 1980's. To the extent that academic courses increase postsecondary education, then the effects of these courses on career earnings for the Class of 1972 may prove to be larger than estimated with the available data. However, the results in the next section indicate that curriculum has only a modest effect on postsecondary education.

\subsection{The Effects of Curriculum on Postsecondary Academic Education}

Although the estimates of the effects of curriculum on wages are not very sensitive to treatment of postsecondary education, it is nevertheless interesting to examine the direct effects of curriculum on college education, since college education has many benefits other than higher wage rates. Columns 5-9 of Table 3 presents OLS estimates of the effect of curriculum on academic education with and without controls for each high school. Columns 1-4 present IV estimates.

The OLS estimates show a strong relationship between postsecondary education and science, foreign language, and math. Even 
when one controls for family background, the OLS coefficients indicate that an additional year of science, foreign language, and math raise education by $.148, .325$, and .261 years (respectively) with small standard errors. (column 6) The corresponding coefficients when one uses OLS with high school fixed effects are to $.222, .343$, and .356 (not shown). The coefficients are substantial even when one controls for aptitude and achievement and for participation in an academic program. The results for the academic and nonacademic subsamples are qualitatively consistent with the results for the combined sample. (See Tables B-5 and B-6.)

The IV estimates paint a very different picture. The coefficients (standard errors) on science and math are only $-.003(.052)$ and $.089(.057)$ for the basic model in column 1. The coefficient on science varies between -.003 and .053 depending on the specification. When one controls for family background, the coefficient on math falls to .042 with a standard error of .038. (column 2) When controls for aptitude and achievement are added, the math coefficient falls to -.011 (column 3).

In summary, the IV estimates indicate that differences across schools in semester hours of science and math have little relationship to educational attainment, even though students from a given high school who take more math and more science go to school longer than students with similar family backgrounds. Among students from the same high school, selection may explain most of the relationship between these variables and postsecondary education. ${ }^{47}$

On the other hand, the estimates of the effects of foreign language courses are much less sensitive to the alternative estimation procedure.

\footnotetext{
${ }^{47}$ The IV results for math and science do not appear to arise from a complicated interaction between foreign language and math and science, because the math and science coefficients change little between columns 1 and 3 of (and change in opposite directions) as the foreign language coefficient falls from .590 to .118 .
} 
education by .339 years with a standard error of .046 , which is less than half of the OLS estimate of .733 years and only a third of the OLS fixed effect estimate of .921 . The effect on YEARSACD of taking the average number of courses/per year in each 5 academic subjects is only .078 .

Finally, the results for HSACAD deserve mention. Many previous studies have found a relationship between HSACAD and educational aspirations or attainment, but cross section studies or studies that compare student from different tracks from the same high school are subject to the problem of selection bias. ${ }^{49}$ HSACAD has a substantial effect on educational attainment even in the IV case. The coefficient on this variable is .8018 when one controls for family background and .4426 when one controls for both family background and aptitude and achievement measures (col. 4). This effect is large given that the mean of YEARSACD is only 1.79 and the number of courses in different subject areas is held constant. A positive correlation between HSACAD and unobserved differences among students and high schools in interest in postsecondary academic education may partially explain this finding. However, there is strong evidence that students in academic programs take more advanced courses in science, foreign language, english, and social studies. (See Rosenbaum (1976) and Adelman (1983)), and so one explanation for the finding that track has an independent effect on wages and education is that the more advanced courses have a larger effect on labor market productivity and the ability to get through college.

\section{Conclusion}

${ }^{49}$ See, for example, Morgan (1984). 
This paper is the first systematic attempt to measure the effects of specific high school courses on wage rates and years of college. Without such information, this is little basis for policy discussions about the effects of changes in high school requirements on labor market success. Evidence relating what a student actually does while in high school or college to labor market success should also help inform the human capital/sorting debate over why years spent in school have economic value. Since descriptive correlations indicate that the quantity and composition of high school courses is related to family background and ability, I use an instrumental variables procedure that relies upon variation across schools in what students take to identify the effects of curriculum. The main finding, which is robust across estimation methods, is that coefficients on courses in the wage equation imply a return to a year of high school courses that is much less than the value of a year spent in high school. The IV estimates for the specification that controls for family background implies that an additional year of math, science, and foreign language would lead to a wage increase of .017 . An increase in all 5 academic subjects by 1 year has a negative effect on wages of about 1 percent. The estimated effect of an extra years worth of courses in all 8 subjects is also negative.

The IV estimates with family background controls indicate that an extra year of math, science, and foreign language would increase postsecondary education by .339 years, and an extra year of all 5 academic subjects leads to an increase of .267. The large OLS and OLS-fixed effects estimates of the effects of science, math, and foreign language on education are overstated.

Many caveats that have been raised about the study, and policy conclusions should not be drawn from the specific estimates. Hopefully, they will stimulate other researchers to go regressions of earnings and on years in school and examine the link between earnings and what students do 
in school. ${ }^{50}$ One obvious approach is to repeat the wage analysis on the High School and Beyond data set (HSB) when additional followup data become available. The HSB High School and Beyond data set contains superior curriculum measures and provides the opportunity to control for ability and aptitude prior to tenth grade. ${ }^{51}$

A second is to match information on minimum curriculum requirements imposed by school districts into the data set, and to use the requirements to identify the effects of curriculum on education and wages. A less ambitious approach is to use variation across states in minimum course requirements in various subjects as identifying information. I have implemented an instrumental variables estimator that uses cross state variation in curriculum to identify the effects of courses on wages. The estimates are basically consistent with the IV estimates, but the standard errors are very large. ${ }^{52}$ One might examine whether state differences in curriculum are related to state differences in education slopes using the much larger US decennial census samples and the methods of Card and Krueger (1990).

A third is to provide a more extensive analysis of the effects of curriculum on wage growth and on the job training. The returns to aptitude

${ }^{50}$ This would parallel recent attempts by Brown (1989) and others who are using data on training to examine the link between experience and wages.

${ }^{51}$ A 1992 followup survey is in progress. Meyer (1992) studies the effects of specific courses on math proficiency using this data set.

52 I obtain a substantial positive coefficient on foreign language and negative coefficients on math and science. The estimated effects of an extra year of each of these subjects is .007 . I also used the 20th percentile for a given high school of semester hours in each subject as instrumental variable under the assumption that cross school variation in this variable might be more closely tied to school district or state requirements than the high school means. The results are similar to those in Table 2 . 
and achievement and to education increase with labor market experience, and it possible that this is also true of science and math. ${ }^{53}$

${ }^{53}$.Altonji and Spletzer (1991) use the NLS72 to examine the link between high school courses and training. They find that the number of courses in science, foreign language, and math does not make much difference once postsecondary education is controlled for. Commercial courses increase training, and the results for social studies, English, and industrial arts are mixed. 


\section{References}

Adelman, Clifford, "Devaluation, Diffusion and the College Connection: A Study of High School Transcripts, 19641981," Postsecondary Studies Team National Institute of Education. Prepared for The National Commission on Excellence in Education (1983).

National Commission on Excellence in Education, $A$ Nation at Risk, Washington, DC, US Government Printing Office (1983).

Alexander, Karl L., and Aaron M. Pallas. "Curriculum Reform and School Performance: An Evaluation of the 'New Basics," American Joumal of Education (August 1984):391-420.

Alexander, Karl L., Martha Cook and Edward McDill. "Curriculum Tracking and Educational Stratification: Some Further Evidence." American Sociological Review 43 (1978):47-66.

Altonji, Joseph G., "The Demand for and Return to Education When Education Outcomes Are Uncertain," NBER working paper No. 3714 (May 1991), forthcoming in Joumal of Labor Economics.

Altonji, Joseph G., "The Effects of Family Background and School Characteristics on Education and Labor Market Outcomes," unpublished paper, Northwestern University (December 1988).

Altonji, Joseph G., and James Spletzer, "Worker Characteristics, Job Characteristics, and the Receipt of On-the-Job Training," Industrial and Labor Relations Review Vol. 45 No. 1 (October 1991): 58-79.

Bishop, John, "Information Externalities and the Social Payoff to Academic Achievement," Cornell University Working Paper No. 87-06.

Bishop, John, "Why High School Students Learn So Little And What Can Be Done About It." Cornell University Working Paper No. 88-01.

Bishop, John and S. Kang, "Why Do Employers Underinvest in On-The-Job Training?," in John Bishop (ed.), Hiring and TRaining Workers, National Center for Research in Vocational Education, Ohio State University, Columbus, Ohio (1984). 
Brown, James, "Why do Wages Increase with Tenure?" American Economic Review Vol 79, No. 5 (December 1989): 971-91.

Campbell, Paul B., Mollie N. Orth, and Patricia Seitz, Patterns of Participation in Secondary Vocational Education, Columbus Ohio: National Center for Research on Vocational Education (1981).

Card, David, and Krueger, Alan, "Does School Quality Matter? Returns to Education and the Characteristics of Public Schools in the United States." Working Paper No. 265, Industrial Relations Section, Princeton University (April 1990).

Crouse, James "The Effects of Academic Ability," in C. Jencks et al., Who Gets Ahead? New York: Basic Books, 1979.

Gamoran, Adam, "The Stratification of High School Learning Opportunities." Sociology of Education, Vol. 60, (July 1987): 135-155.

Garet, Michael S. and Brian DeLaney, "Students, Courses and Stratification." Sociology of Education, Vol. 61, April 1988: pp. 61-77.

Heyns, Barbara, "Social Selection and Stratification within Schools." American Joumal of Sociology, Vol. 79, Number 6 (1974).

Lee, Valerie E. and Anthony S. Bryk, "Curriculum Tracking As Mediating the Social Distribution of High School Achievement." Sociology of Education 61 (1988):78-94.

Meyer, Robert, “Applied versus Traditional Mathematics: New Econometric Models of the Contribution of High School Courses to Mathematics Proficiency." unpublished paper, University of Wisconsin (January 1992).

Morgan, William R., "Quantity of Learning and Quality of Life for Public and Private High School Youth," in Michael E. Borus (ed.), "Youth and the Labor Market." W. E. Upjohn Institute for Employment Research (1984):157-192.

Murphy, K. M. and F. Welch, "The Structure of Wages." Quarterly Joumal of Economics, CVII No. 1 (February 1992): 285-326. 
Rosenbaum, James E., Making Inequality. New York: Wiley (1976).

Rumberger, Russell W. and Daymont, Thomas N., "The Economic Value of Academic and Vocational Training Acquired in High School, in Borus, Michael E. (ed.), "Youth and the Labor Market, W. E. Upjohn Institute for Employment Research (1984):157-192.

Sorensen, A. B., "The Structure of Inequality and the Process of Attainment." American Sociological Review, Vol. 42 (December 1977): 965-978.

Vanfossen, Beth E.; Jones, James D. and Joan Z. Spade. "Curriculum Tracking and Status Maintenance." Sociology of Education Vol. 60 (April 1987):104-122.

Weiss, Andrew, "Human Capital and Sorting Models," mimeo, Department of Economics, Boston University (July 1990).

Willis, Robert J. and Sherwin Rosen, "Education and Self Selection," Joumal of Political Economy, 87(2) (1979):S7-S36

Willis, Robert J., "Wage Determinants: A Survey and Reinterpretation of Human Capital Earnings Functions," in O. Ashenfelter and R. Layard (eds.), Handbook of Labor Economics (1987). 
Table 1

Means and Standard Deviations of Semester Hrs and Fraction of Semester Hours by Subject

\begin{tabular}{|c|c|c|c|c|c|c|c|c|c|c|c|c|}
\hline & \multicolumn{4}{|c|}{ Combined Suple } & \multicolumn{4}{|c|}{ Acadolc } & \multicolumn{4}{|c|}{ Honecaderte } \\
\hline & (1) & (2) & (3) & $(\omega)$ & (5) & (6) & (7) & (8) & (日) & (10) & (11) & (12) \\
\hline $\begin{array}{l}\text { Expl matory } \\
\text { Veriables }\end{array}$ & Mn & SD & $\begin{array}{l}\text { SD } \\
\text { In } \\
\text { ES }\end{array}$ & $\begin{array}{l}\text { Fraction } \\
\text { of } \\
\text { Variane } \\
\text { Across } \\
\text { Gigh } \\
\text { Sehools }\end{array}$ & $M m$ & SD & $\begin{array}{l}\text { SD } \\
\text { in } \\
\text { BS }\end{array}$ & $\begin{array}{l}\text { Eraction } \\
\text { of } \\
\text { Vartance } \\
\text { Acroes } \\
\text { Eigh }\end{array}$ & Man & SD & $\begin{array}{l}\text { So } \\
\text { in } \\
\text { BS }\end{array}$ & $\begin{array}{l}\text { Fraction } \\
\text { of } \\
\text { Variance } \\
\text { Across } \\
\text { Blgh } \\
\text { Schools }\end{array}$ \\
\hline
\end{tabular}

ACADDMC PROG. 0.4522

1.0

0.0

Smenter Bours

\begin{tabular}{|c|c|c|c|c|c|c|c|c|c|c|c|c|}
\hline SCIENICE & 18.725 & 10.081 & B. 678 & 0.258 & 23.308 & 9.691 & 8.082 & 0.308 & 14.243 & 8.760 & 7.099 & 0.360 \\
\hline FOR. LANG & 10.867 & 11.322 & 9.685 & 0.268 & 16.084 & 11.016 & 9.188 & 0.304 & 5.883 & 8.884 & 7.229 & 0.203 \\
\hline SOCLAL.SI & 26.231 & 7.671 & 5.846 & 0.418 & 26.457 & 7.672 & 5.804 & 0.427 & 26.044 & 7.666 & 5.798 & 0.427 \\
\hline DNCLISB & 28.985 & 5.507 & 4.690 & 0.496 & 30.680 & 6.413 & 4.454 & 0.517 & 20.429 & 6.710 & 4.578 & 0.334 \\
\hline MATH & 19.179 & 9.992 & 0.570 & 0.264 & 23.900 & 0.706 & 7.390 & 0.270 & 15.283 & 9.281 & 7.543 & 0.339 \\
\hline IND. ARTS & 3.614 & 11.902 & 11.210 & 0.112 & 3.490 & 0.530 & B. 103 & 0.097 & 7.367 & 23.847 & 13.003 & 0.118 \\
\hline COMBRCLAL & 14.054 & 16.505 & 15.304 & 0.140 & 8.468 & 10.304 & 9.289 & 0.218 & 18.665 & 18.052 & 16.835 & 0.210 \\
\hline FIRE.ARTS & 8.686 & 13.172 & 11.794 & 0.188 & 9.303 & 13.735 & 12.315 & 0.196 & 0.177 & 12.667 & 11.314 & 0.202 \\
\hline s. & 133.331 & 31.122 & 22.636 & 0.470 & 142.489 & 29.030 & 19.610 & 0.543 & 123.772 & 30.760 & 22.326 & 0.473 \\
\hline
\end{tabular}

Precticen of semestar Bours in Each subject

\begin{tabular}{|c|c|c|c|c|c|c|c|c|c|c|c|c|}
\hline SCIENCE & 0.138 & 0.067 & 0.061 & 0.184 & 0.163 & 0.060 & 0.054 & 0.185 & 0.118 & 0.066 & 0.056 & 0.271 \\
\hline FOR. LANG & 0.076 & 0.077 & 0.067 & 0.246 & 0.116 & 0.072 & 0.062 & 0.273 & 0.043 & 0.064 & 0.058 & 0.180 \\
\hline SOCINL.ST & 0.203 & 0.064 & 0.056 & 0.294 & 0.189 & 0.054 & 0.047 & 0.264 & 0.214 & 0.069 & 0.056 & 0.339 \\
\hline ENG ISE & 0.233 & 0.062 & 0.050 & 0.341 & 0.220 & 0.051 & 0.041 & 0.366 & 0.243 & 0.068 & 0.054 & 0.374 \\
\hline MII & 0.141 & 0.068 & 0.051 & 0.187 & 0.167 & 0.054 & 0.051 & 0.126 & 0.120 & 0.070 & 0.050 & 0.282 \\
\hline IND. ARTS & 0.042 & 0.087 & 0.082 & 0.103 & 0.026 & 0.057 & 0.055 & 0.085 & 0.058 & 0.203 & 0.097 & 0.111 \\
\hline COMMRCIAL & 0.106 & 0.122 & 0.114 & 0.135 & 0.059 & 0.074 & 0.066 & 0.213 & 0.144 & 0.160 & 0.125 & 0.193 \\
\hline PIMR.ARIS & 0.060 & 0.088 & 0.080 & 0.183 & 0.061 & 0.086 & 0.078 & 0.188 & 0.060 & 0.090 & 0.081 & 0.180 \\
\hline
\end{tabular}

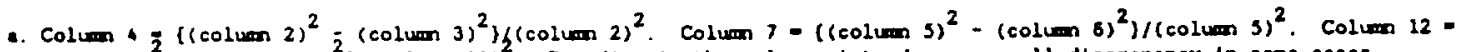
(icolum 10$)^{2}$ ! (colum 11$)^{2}$ ) $(\text { colum } 10)^{2}$. Rounding in the colums introduces amall discropancy in sone cases. Within bieh school atanderd deviation estimates in this table and Iable A-1 are adjunted for degrees of freedoen. 
Table 2

The Effects of High School Curriculum on Vages

Dependent Varlable: Log Average Hourly Wage in 1967 Dollars

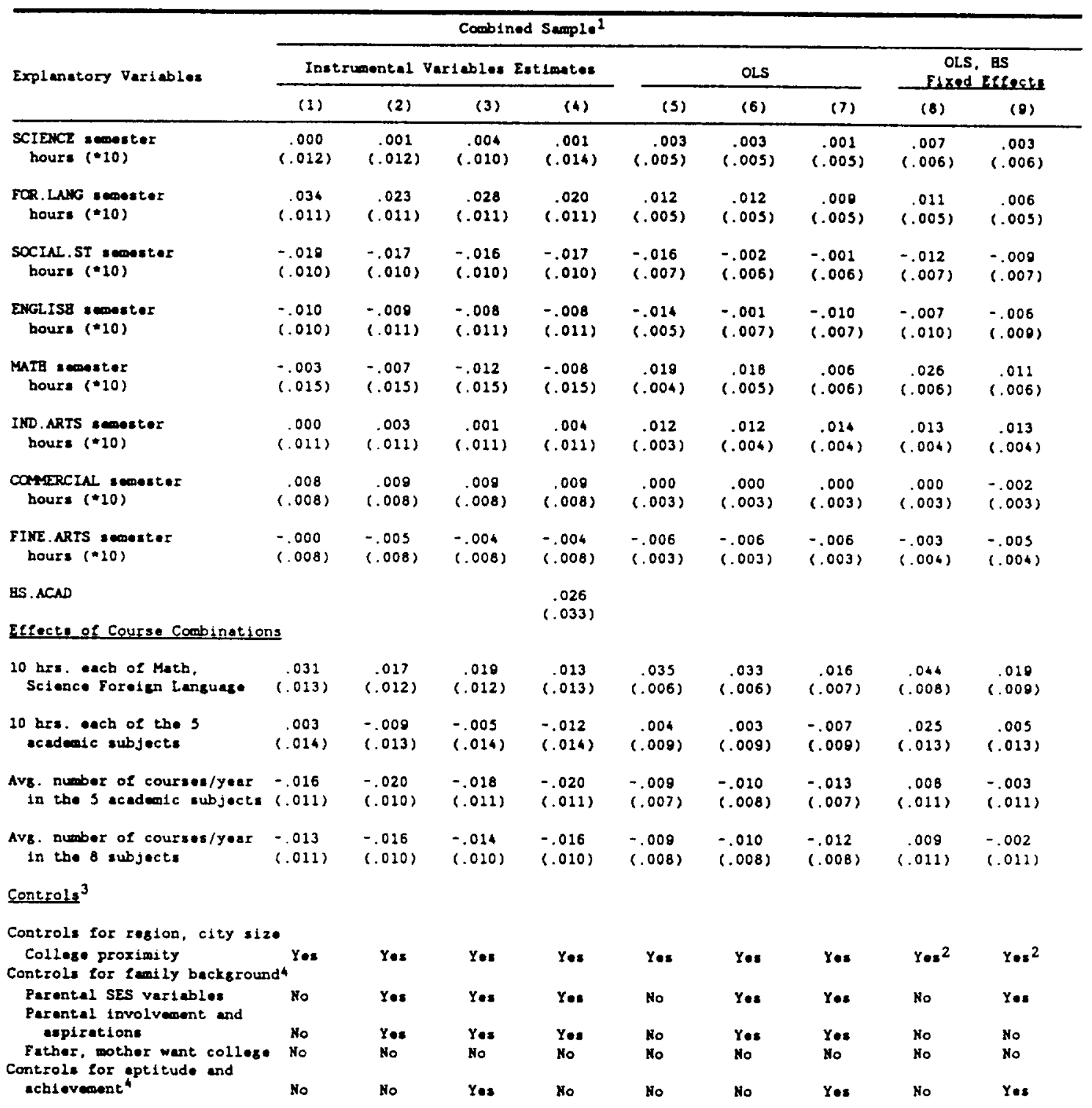

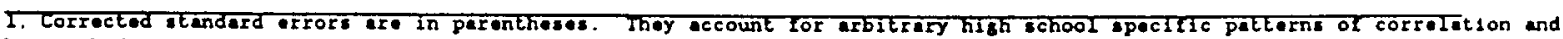
hetoroskedesticity, The estimator are defined in the text.

2. Equetion includes high echool specific intercepts, which fmplicitly control for ell hish school epecific variables. lacludins location.

3. For a llet of the control variables sue the text and Appondix Ieble A.1.

1. In the IV case both values for the Individuel and high shool means are included. In the ols case only individuel velues are included. 
rable 3

The zefects of High Sebool Curriculin on Yoars of Pont Secopdery Education Dopeodeat Varlable: Trunsico

\begin{tabular}{|c|c|c|c|c|c|c|c|c|c|}
\hline \multirow{3}{*}{ Explanetory Variables } & \multicolumn{7}{|c|}{ Coobined Sample } & & \\
\hline & \multicolumn{3}{|c|}{ Instrumental Yortables } & \multirow[b]{2}{*}{ (4) } & \multicolumn{3}{|c|}{ OLS } & \multicolumn{2}{|c|}{ Fixglentects } \\
\hline & (1) & (2) & (3) & & (s) & (6) & (7) & (s) & (9) \\
\hline $\begin{array}{l}\text { SCIENCE scoester } \\
\text { bours }(* 10)\end{array}$ & $\begin{array}{l}-.003 \\
(.052)\end{array}$ & $\begin{array}{l}.041 \\
(.042)\end{array}$ & $(.053)$ & $\begin{array}{l}.047 \\
(.036)\end{array}$ & $\begin{array}{l}.179 \\
(.021)\end{array}$ & $\begin{array}{l}.148 \\
(.029)\end{array}$ & $\begin{array}{l}.079 \\
(.018)\end{array}$ & $\begin{array}{l}.270 \\
(.021)\end{array}$ & $\begin{array}{l}.118 \\
(.020)\end{array}$ \\
\hline $\begin{array}{l}\text { FOR, LNNG seopester } \\
\text { bours ("10) }\end{array}$ & $\begin{array}{l}.390 \\
(.052)\end{array}$ & $\begin{array}{l}.257 \\
(.042)\end{array}$ & $\begin{array}{l}.218 \\
(.039)\end{array}$ & $\begin{array}{l}.071 \\
(.040)\end{array}$ & $\begin{array}{l}.633 \\
(.019)\end{array}$ & $\begin{array}{l}.325 \\
(.018)\end{array}$ & $\begin{array}{l}.187 \\
(.017)\end{array}$ & $\begin{array}{l}.416 \\
(.010)\end{array}$ & $\begin{array}{l}.195 \\
(.018)\end{array}$ \\
\hline $\begin{array}{l}\text { SOCIAL.ST wowester } \\
\text { bours ("10) }\end{array}$ & $\begin{array}{l}-.093 \\
(.042)\end{array}$ & $\begin{array}{l}-.043 \\
(.037)\end{array}$ & $\begin{array}{l}-.019 \\
(.033)\end{array}$ & $\begin{array}{l}-.013 \\
(.033)\end{array}$ & $\begin{array}{l}.061 \\
(.026)\end{array}$ & $\begin{array}{l}-.041 \\
(.022)\end{array}$ & $\begin{array}{l}-.010 \\
(.020)\end{array}$ & $\begin{array}{l}.046 \\
(.027)\end{array}$ & $\begin{array}{l}.065 \\
(.024)\end{array}$ \\
\hline $\begin{array}{l}\text { EHGLISB smexter } \\
\text { bours }(* 10)\end{array}$ & $\begin{array}{l}-.033 \\
(.052)\end{array}$ & $\begin{array}{l}-.030 \\
(.043)\end{array}$ & $\begin{array}{l}.010 \\
(.037)\end{array}$ & $\begin{array}{l}.018 \\
(.037)\end{array}$ & $\begin{array}{l}.020 \\
(.032)\end{array}$ & $\begin{array}{l}-.020 \\
(.029)\end{array}$ & $(.025)$ & $\begin{array}{l}.143 \\
(.039)\end{array}$ & $\begin{array}{l}.098 \\
(.033)\end{array}$ \\
\hline $\begin{array}{l}\text { MATB soosester } \\
\text { hours }(* 10)\end{array}$ & $\begin{array}{l}.089 \\
(.057)\end{array}$ & $\begin{array}{l}.042 \\
(.038)\end{array}$ & $\begin{array}{l}-.012 \\
(.043)\end{array}$ & $\begin{array}{l}-.013 \\
(.042)\end{array}$ & $\begin{array}{l}.329 \\
(.020)\end{array}$ & $\begin{array}{l}.261 \\
(.010)\end{array}$ & $\begin{array}{l}.123 \\
(.018)\end{array}$ & $\begin{array}{l}.424 \\
(.021)\end{array}$ & $\begin{array}{l}.101 \\
(.020)\end{array}$ \\
\hline $\begin{array}{l}\text { IND. ARTS sooster } \\
\text { hours }(* 10)\end{array}$ & $\begin{array}{l}-.197 \\
(.044)\end{array}$ & $\begin{array}{l}-.135 \\
(.026)\end{array}$ & $\begin{array}{l}-.089 \\
(.036)\end{array}$ & $\begin{array}{l}-.070 \\
(.034)\end{array}$ & $\begin{array}{l}-.170 \\
(.014)\end{array}$ & $\begin{array}{l}-.130 \\
(.013)\end{array}$ & $\begin{array}{r}-.086) \\
(.022)\end{array}$ & $\begin{array}{l}-.125 \\
(.015)\end{array}$ & $\begin{array}{l}-.074 \\
(.013)\end{array}$ \\
\hline $\begin{array}{l}\text { COMmERCIAL, smeater } \\
\text { hours }(* 10)\end{array}$ & $\begin{array}{l}-.161 \\
(.033)\end{array}$ & $\begin{array}{l}-.071 \\
(.026)\end{array}$ & $\begin{array}{l}-.039 \\
(.023)\end{array}$ & $\begin{array}{l}-.034 \\
(.022)\end{array}$ & $\begin{array}{l}-.124 \\
(.011)\end{array}$ & $\begin{array}{l}-.098 \\
(.010)\end{array}$ & $\begin{array}{l}-.081 \\
(.000)\end{array}$ & $\begin{array}{l}-.061 \\
(.012)\end{array}$ & $\begin{array}{l}-.068 \\
(.010)\end{array}$ \\
\hline $\begin{array}{l}\text { FIME. ARTS } * \text { enester } \\
\text { hour: }(\star 10)\end{array}$ & $(.031)$ & $\begin{array}{l}.019 \\
(.026)\end{array}$ & $\begin{array}{l}.021 \\
(.023)\end{array}$ & $\begin{array}{l}.022 \\
(.023)\end{array}$ & $\begin{array}{l}.066 \\
(.013)\end{array}$ & $(.034$ & $\begin{array}{l}.030 \\
(.011)\end{array}$ & $\begin{array}{l}.073 \\
(.016)\end{array}$ & $\begin{array}{l}.032 \\
(.012)\end{array}$ \\
\hline ES ACAD & 一 & 一 & - & $\begin{array}{c}.433 \\
(.110)\end{array}$ & - & & & & \\
\hline \multicolumn{10}{|l|}{ Efeects of Course Combinations } \\
\hline $\begin{array}{l}10 \text { hrs. Oach of Math. } \\
\text { Sclonce Foreien Language }\end{array}$ & $\begin{array}{l}.635 \\
(.054)\end{array}$ & $\begin{array}{l}.339 \\
(.046)\end{array}$ & $\begin{array}{l}.150 \\
(.046)\end{array}$ & $(.046)$ & $\begin{array}{l}.941 \\
(.026)\end{array}$ & $\begin{array}{l}.733 \\
(.026)\end{array}$ & $\begin{array}{l}.389 \\
(.026)\end{array}$ & $\begin{array}{l}1.12 \\
(.026)\end{array}$ & $(.504)$ \\
\hline $\begin{array}{l}10 \text { hre. each of thes } \\
\text { acederic subject. }\end{array}$ & $\begin{array}{l}.550 \\
(.065)\end{array}$ & $\begin{array}{l}.267 \\
(.056)\end{array}$ & $\begin{array}{l}.151 \\
(.051)\end{array}$ & $\begin{array}{c}.111 \\
(.051)\end{array}$ & $(.860$ & $\begin{array}{l}.672 \\
(.041)\end{array}$ & $(.0395)$ & $\begin{array}{l}1.30 \\
(.054)\end{array}$ & $\begin{array}{l}.668 \\
(.046)\end{array}$ \\
\hline $\begin{array}{l}\text { Ave. number of courses/yenr } \\
\text { if the } 5 \text { acadenic subjects }\end{array}$ & $.051)$ & $\begin{array}{l}.078 \\
(.042)\end{array}$ & $(.062$ & $(.034)$ & $(.037)$ & $(.0320)$ & $\begin{array}{l}.203 \\
(.029)\end{array}$ & $\begin{array}{l}.772 \\
(.067)\end{array}$ & $\begin{array}{l}.421 \\
(.038)\end{array}$ \\
\hline $\begin{array}{l}\text { Avg. number of courses/yane } \\
\text { in the a subjects }\end{array}$ & .086 & $\begin{array}{l}.025 \\
(.045)\end{array}$ & $\begin{array}{l}.033 \\
(.038)\end{array}$ & $\begin{array}{l}.032 \\
(.037)\end{array}$ & $\begin{array}{l}.339 \\
(.040)\end{array}$ & $\begin{array}{c}.258 \\
(.038)\end{array}$ & $\begin{array}{l}.158 \\
(.031)\end{array}$ & $\begin{array}{c}.761 \\
(.050)\end{array}$ & $\begin{array}{l}.385 \\
(.061)\end{array}$ \\
\hline \multicolumn{10}{|l|}{ Controls ${ }^{3}$} \\
\hline $\begin{array}{l}\text { Controls for resion, city } 112 \\
\text { Collese proxinlty } \\
\text { Controls for fand ty backeroun }\end{array}$ & nd $^{20}$ Yos & Yos & Yos & Yes & Yea & Yoe & $Y \bullet$ & $Y \circ \mathbb{S}^{2}$ & $Y \bullet x^{2}$ \\
\hline $\begin{array}{l}\text { Parestal SES veriables } \\
\text { Parontel involvement and } \\
\text { aspirations } \\
\text { Father, mother want college } \\
\text { Controls ear eptitude and } \\
\text { achievement }\end{array}$ & $\begin{array}{l}\text { No } \\
\text { No } \\
\text { No } \\
\text { No }\end{array}$ & $\begin{array}{l}\text { Yos } \\
\text { No }\end{array}$ & $\begin{array}{l}\text { Yes } \\
\text { No }\end{array}$ & $\begin{array}{l}\text { Yes } \\
\text { No }\end{array}$ & $\begin{array}{l}\text { No } \\
\text { Ho } \\
\text { Ho }\end{array}$ & $\begin{array}{l}\text { Yos } \\
\text { Yes } \\
\text { No }\end{array}$ & $\begin{array}{l}\text { Yos } \\
\text { Yos } \\
\text { No }\end{array}$ & $\begin{array}{l}\text { No } \\
\text { No } \\
\text { No }\end{array}$ & $\begin{array}{l}\text { Yes } \\
\text { Yos } \\
\text { No }\end{array}$ \\
\hline
\end{tabular}

1. 2. 3. 4. S৫e Table 2 . 
Table A-1

Means and Standard Deviations of Vage and Education Variables, Hage Sarple*

\begin{tabular}{|c|c|c|c|c|c|c|c|c|}
\hline \multirow{3}{*}{ Explanatory Variabloe } & \multicolumn{4}{|c|}{ Combined suple } & \multicolumn{2}{|c|}{ Acadeate } & \multicolumn{2}{|c|}{ Non-Acad alc $1 \mathrm{c}$} \\
\hline & (1) & (2) & (3) & (4) & (5) & (6) & (7) & (b) \\
\hline & $\operatorname{man}$ & $\mathrm{so}$ & 30 in ES & $\begin{array}{l}\text { Fraction of } \\
\text { Yertenes Acros: } \\
\text { Hich Schools }\end{array}$ & Mean & so & Mon & SD \\
\hline \multicolumn{9}{|l|}{ Wages } \\
\hline $\begin{array}{l}\text { LOGAGE los of real ivg. } \\
\text { bourly wase. } 67 \text { dollars }\end{array}$ & .8196 & .4635 & .4402 & .0980 & .9016 & .4746 & .8523 & .4425 \\
\hline \multicolumn{9}{|l|}{ Education } \\
\hline \multicolumn{9}{|l|}{ YEARSACD year of post- } \\
\hline $\begin{array}{l}\text { recc. aced. Od. by } 1070 \\
\text { Eec. voc. ed by } 1070\end{array}$ & 1.988 & 1.843 & 1.668 & .1829 & 2.936 & 1.753 & 1.102 & 1.438 \\
\hline $\begin{array}{l}\text { vece. voc. od by } 1970 \\
\text { voeational, no college } \\
\text { by } 70\end{array}$ & .5309 & .7641 & .7183 & .1163 & .5228 & 0.786 & 0.5385 & .7347 \\
\hline Sarzcolt 1 is lese than 2 & .0851 & -- & $\cdots$ & -- & .0381 & -- & .1290 & -- \\
\hline $\begin{array}{l}\text { yeara college by } 79 \\
\text { sorecols } 1 \text { if more than } 2\end{array}$ & .1803 & -- & $-\cdot$ & -- & .2413 & -- & .2168 & -- \\
\hline $\begin{array}{l}\text { years college, no deeree } \\
\text { COLLDEE } 1 \text { if colloge desree, }\end{array}$ & .1738 & -- & -- & - & .1095 & -- & .1497 & $\cdots$ \\
\hline $\begin{array}{l}\text { no advanced desree by } 79 \\
\text { ADVAMCED } 1 \text { if advanced }\end{array}$ & .3022 & -- & -- & - & .4928 & -- & .1240 & -- \\
\hline decree by 79 & .0285 & -- & -- & $\cdots$ & .0534 & - & .0053 & -- \\
\hline \multicolumn{9}{|l|}{ Gader ad Rece/tEthictit } \\
\hline BLACK & .0892 & -- & -- & - & .0663 & -- & .1106 & -- \\
\hline EISP & .0366 & -- & - & -- & .0213 & +- & .0500 & -- \\
\hline FOAALE & .4916 & -- & -- & $\cdots$ & .4780 & -- & .5043 & $\cdots$ \\
\hline \multicolumn{9}{|l|}{ Folly Beckerouad } \\
\hline CFAED Eather's education & 12.75 & 2.545 & 2.171 & .2723 & 13.49 & 2.632 & 12.06 & 2.250 \\
\hline OxowD wother's education & 12.43 & 2.098 & 1.854 & .2101 & 12.06 & 2.158 & 21.03 & 1.190 \\
\hline $\begin{array}{l}\text { LOSES } 1 \text { if low SES } \\
\text { BQ17JMA I if worry over } \\
\text { money interfered with }\end{array}$ & .2340 & -- & -- & - & .1343 & .3410 & .3273 & .4692 \\
\hline $\begin{array}{l}\text { BS aducation } \\
\text { MRTE } 1 \text { if mother worked } \\
\text { while in elementary }\end{array}$ & .2891 & -- & -- & $\cdots$ & .2261 & .4183 & .3480 & .6764 \\
\hline $\begin{array}{l}\text { ichool } \\
\text { Buteotr2 } 1 \text { if tether }\end{array}$ & .4021 & + & $\cdots$ & -- & .3804 & .4855 & .4223 & .4938 \\
\hline $\begin{array}{l}\text { blue collar } \\
\text { Bos8 } 1 \text { if English spaken }\end{array}$ & .3216 & -- & $\cdots$ & -- & .2925 & .4548 & .3488 & .4766 \\
\hline noothe if if father wants & .9207 & -- & -- & - & .0183 & .2739 & 9230 & .2666 \\
\hline $\begin{array}{l}\text { collese or srad school } \\
\text { wcoll2 if wother wants }\end{array}$ & .5787 & $\cdots$ & + & -- & .7814 & .4133 & .3880 & .4875 \\
\hline $\begin{array}{l}\text { collese or srad school } \\
\text { PLNADSCD } 1 \text { if often } \\
\text { discursed plans with }\end{array}$ & .6140 & -- & -- & -- & .8183 & .3856 & .4229 & .4840 \\
\hline $\begin{array}{l}\text { Parente } \\
\text { BQ17FUIF } 1 \text { if uninterested } \\
\text { perente interfored }\end{array}$ & .7902 & -- & $\cdots$ & -- & .8510 & .3561 & .7332 & .6423 \\
\hline $\begin{array}{l}\text { with high school } \\
\text { PLANINR i if parents } \\
\text { influenced post BS }\end{array}$ & .2019 & -- & -- & -- & .1272 & .3332 & .2738 & .4640 \\
\hline pland a dent doal & .4397 & -- & $\cdots$ & -- & .5037 & .5000 & .3798 & .4854 \\
\hline
\end{tabular}


Table A-1, continand

then and stedard Doriation

\begin{tabular}{|c|c|c|c|c|c|c|c|c|}
\hline \multirow{3}{*}{ Explenatory Variublen } & \multicolumn{4}{|c|}{ Combined 5 mole } & \multicolumn{2}{|c|}{ Acedente } & \multicolumn{2}{|c|}{ Mon-Acadente } \\
\hline & (1) & (2) & (3) & (4) & (s) & (6) & (7) & (8) \\
\hline & Man an & 50 & SD in ES & $\begin{array}{c}\text { Frection of } \\
\text { Verlance Across } \\
\text { Bieh Schools }\end{array}$ & Mean & sD & Men & SD \\
\hline \multicolumn{9}{|l|}{ Coceraphle Vaxibles } \\
\hline Sertan & .2953 & $=-$ & $\cdots$ & $-\cdot$ & .3027 & $\cdots$ & .2883 & $\cdots$ \\
\hline MD.CIT & .0832 & -- & $\cdots$ & -- & .0863 & -- & .0802 & $\cdots$ \\
\hline MED. SUBURA & .0487 & -- & -- & -- & .0596 & -- & .0386 & -- \\
\hline DICIIY & .1020 & -- & -- & $\cdots$ & .0955 & $-\cdot$ & .1080 & -- \\
\hline BIGSUBLAR & .1046 & -- & -- & - & .1171 & $=$ & .0930 & -- \\
\hline 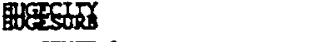 & :8338 & $z$ & $\because=$ & $:=$ & : 1999 & $\because:$ & $: 8986$ & $\because$ \\
\hline Wo. cormul. & .2916 & -- & $\cdots$ & $\cdots$ & .2750 & -- & .3072 & - \\
\hline sourti & .3276 & - & -- & - & .2737 & -- & .3585 & $\cdots$ \\
\hline VEST & .1678 & -- & -- & -- & .1661 & -- & .2880 & -- \\
\hline COLI- PRosx & 1.785 & -- & -- & -- & 1.702 & -- & 1.863 & - \\
\hline \multicolumn{9}{|l|}{ Apeittado ad schiovent } \\
\hline $\begin{array}{l}\text { DPTAVIR sxados } \\
\text { Bozs college material }\end{array}$ & 15.64 & 7.586 & 3.469 & .7209 & 14.46 & 7.437 & 16.76 & 7.553 \\
\hline $\begin{array}{l}\text { 1-definitely; Soder, not } \\
\text { sq140 teacher }\end{array}$ & 1.843 & .9659 & .8984 & .1340 & 1.677 & .8091 & 2.186 & 2.092 \\
\hline $\begin{array}{l}\text { expectation of student } \\
\text { (s-low, 1-hieh) }\end{array}$ & 2.085 & .8701 & .8227 & .1060 & 1.816 & .7948 & 2.337 & .8621 \\
\hline WOCABULARY & 52.31 & 9.896 & 8.640 & .2377 & 56.34 & 9.328 & 48.54 & 0.072 \\
\hline PICTLRE. MUte assoctetive & & & & & & & & \\
\hline mory & 31.37 & 9.680 & 8.838 & .1674 & 53.73 & 9.138 & 49.54 & 9.720 \\
\hline RIADDAG & 52.31 & 9.424 & 8.450 & .1945 & 56.07 & 8.321 & 48.80 & 9.033 \\
\hline $\begin{array}{l}\text { terTher.Gour inductive } \\
\text { raseonins }\end{array}$ & 52.33 & 8.878 & 8.034 & .1811 & 55.33 & 7.082 & 49.54 & 0.456 \\
\hline $\begin{array}{l}\text { MrT quentitative } \\
\text { comparisons basic }\end{array}$ & & & & & & & & \\
\hline BO7 bours on bommork/wed & 4.467 & 3.278 & 3.018 & .1523 & 3.315 & 3.642 & 3.674 & 2.890 \\
\hline
\end{tabular}

- Desclptive stetistice are based on the copples used to estimate the wage models and are somomat different for the educstion

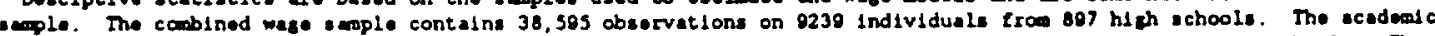

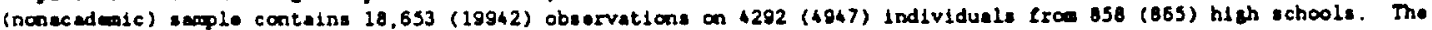
doscripelve statistica in tabl. 1 are based on the educetion smple. 
Table $\mathbf{1 - 1}$

The Effecte of Eigh scbool Curriculo on Lagee

Dependent Vexisble: Lo Averese Bourly

Naee is 1067 Dollars

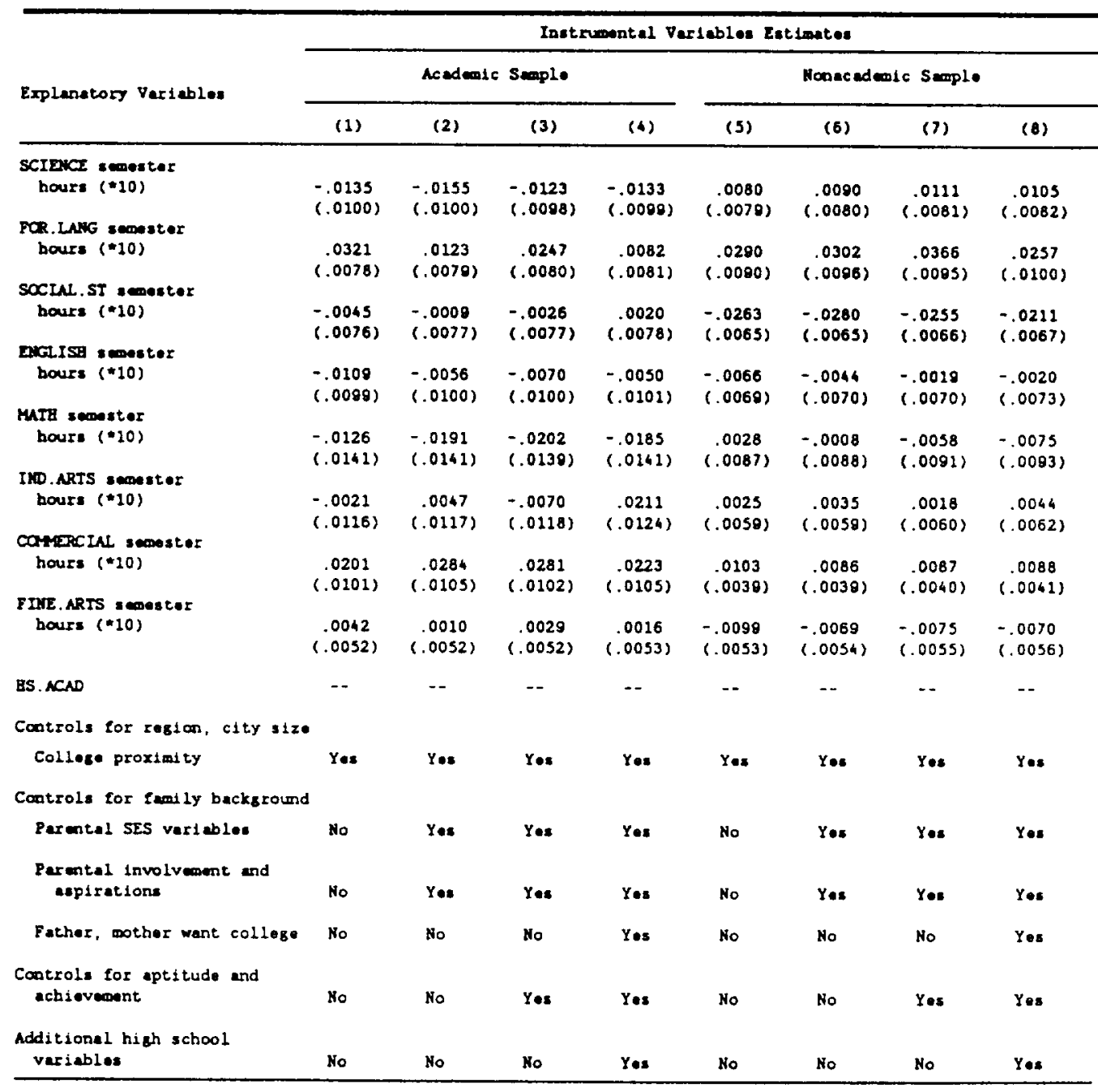

- Standard Errors are conventional 2SLS standard errors and do not account for sertal correlation over time for the seme person and ans persons fram the same high schools. Correctod itandard errors were computed for severel models and are person and mong persons from the sme high schools. Corrected itandard or 
Table $\mathbf{B}-4$

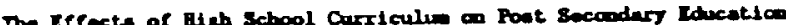
Depodat Veriablo: yosac79

\begin{tabular}{|c|c|c|c|c|c|c|c|c|}
\hline \multirow{3}{*}{ Explenatory Varlables } & \multicolumn{8}{|c|}{ Instrumentel Variablon Estimates } \\
\hline & \multicolumn{4}{|c|}{ Acedemic S enple } & \multicolumn{4}{|c|}{ Nonecedeale Suple } \\
\hline & (1) & (2) & (3) & (4) & (s) & (6) & (7) & (B) \\
\hline $\begin{array}{l}\text { Far.LANG soopeter } \\
\text { bours }(\$ 10)\end{array}$ & $\begin{array}{l}.3023 \\
(.0569)\end{array}$ & $\begin{array}{l}.1280 \\
(.0565)\end{array}$ & $(.0522)$ & $\begin{array}{l}.1070 \\
(.0528)\end{array}$ & $\begin{array}{l}.3487 \\
(.0501)\end{array}$ & $\begin{array}{l}.0493 \\
(.0564)\end{array}$ & $\begin{array}{l}.0038 \\
(.0514)\end{array}$ & $\begin{array}{l}.0185 \\
(.0512)\end{array}$ \\
\hline $\begin{array}{l}\text { Soclal.SI semester } \\
\text { bours }(=10)\end{array}$ & $\begin{array}{l}-.1189 \\
(.0567)\end{array}$ & $\begin{array}{l}-.0296 \\
(.0544)\end{array}$ & $(.0002)$ & $\begin{array}{l}-.0059 \\
(.0506)\end{array}$ & $\begin{array}{l}-.0220 \\
(.0368)\end{array}$ & $\begin{array}{l}-.0061 \\
(.0356)\end{array}$ & $\begin{array}{l}-.0067 \\
(.0340)\end{array}$ & $\begin{array}{l}-.0088 \\
(.0326)\end{array}$ \\
\hline $\begin{array}{l}\text { MTg sedester } \\
\text { hours }(* 10)\end{array}$ & $\begin{array}{l}.1408 \\
(.0973)\end{array}$ & $\begin{array}{l}.1088 \\
(.0928)\end{array}$ & $(.0584$ & $\begin{array}{l}.1170 \\
(.0858)\end{array}$ & $\begin{array}{l}.0251 \\
(.0460)\end{array}$ & $\begin{array}{l}.0001 \\
(.0457)\end{array}$ & $\begin{array}{l}-.0268 \\
(.0442)\end{array}$ & $\begin{array}{l}-.0046 \\
(.0627)\end{array}$ \\
\hline $\begin{array}{l}\text { IND. ARTS emoster } \\
\text { hours }(\$ 10)\end{array}$ & $\begin{array}{l}-.1860 \\
(.0878)\end{array}$ & $\begin{array}{l}-.0855 \\
(.0028)\end{array}$ & $\begin{array}{l}-.0897 \\
(.0818)\end{array}$ & $\begin{array}{l}-.1746 \\
(.0826)\end{array}$ & $\begin{array}{l}-.1068 \\
(.0352)\end{array}$ & $\begin{array}{l}-.0802 \\
(.0342)\end{array}$ & $\begin{array}{l}-.0644 \\
(.0327)\end{array}$ & $\begin{array}{l}-.0587 \\
(.0322)\end{array}$ \\
\hline $\begin{array}{l}\text { Carrscill semester } \\
\text { bours }(+10)\end{array}$ & $\begin{array}{l}-.0288 \\
(.0745)\end{array}$ & $\begin{array}{l}-.0912 \\
(.0739)\end{array}$ & $\begin{array}{l}-.0438 \\
(.0681)\end{array}$ & $\begin{array}{l}.0445) \\
(.0890)\end{array}$ & $\begin{array}{l}-.0390 \\
(.0216)\end{array}$ & $\begin{array}{l}-.0269 \\
(.0210)\end{array}$ & $\begin{array}{l}-.0068 \\
(.0203)\end{array}$ & $\begin{array}{l}-.0030 \\
(.0194)\end{array}$ \\
\hline $\begin{array}{l}\text { FIRE. ARTS semester } \\
\text { hours }(* 10)\end{array}$ & $\begin{array}{l}.1503 \\
(.0385)\end{array}$ & $\begin{array}{l}.0383 \\
(.0373)\end{array}$ & $\begin{array}{l}.0470 \\
(.0352)\end{array}$ & $\begin{array}{l}.0303 \\
(.0346)\end{array}$ & $\begin{array}{l}.0851 \\
(.0206)\end{array}$ & $\begin{array}{l}.0013 \\
(.0294)\end{array}$ & $\begin{array}{l}-.0153 \\
(.0283)\end{array}$ & $\begin{array}{l}-.0446 \\
(.0276)\end{array}$ \\
\hline HS. ACAD & - & -- & -- & -- & -- & -- & -- & $\cdots$ \\
\hline $\begin{array}{l}\text { Control. Lor resion, city } 1 z 0 \\
\text { Collese proxindty }\end{array}$ & Yes & Yos & Yes & $Y \bullet$ & Yo: & Yos & Yes & $Y \bullet$ \\
\hline $\begin{array}{l}\text { Controls for fomily becks round } \\
\text { Parentel ses vartables }\end{array}$ & Mo & 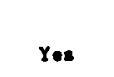 & $Y \in$ & Yes & Mo & Yas & Yes & Yes \\
\hline $\begin{array}{l}\text { Parcatel involvament and } \\
\text { espirations }\end{array}$ & Mo & Yes & Yos & Ye⿻ & so & Yes & Yo: & Yes \\
\hline Father, mother want college & No & Mo & Mo & Y॰d & No & No & Mo & Y॰s \\
\hline $\begin{array}{l}\text { Controls for aptitude and } \\
\text { echiovement }\end{array}$ & Mo & Ho & Yeะ & Yos & Mo & Mo & Yos & Ye⿻ \\
\hline $\begin{array}{l}\text { Addit lonal bich school } \\
\text { variables }\end{array}$ & no & No & Ho & Yes & Mo & Ho & no & Yes \\
\hline
\end{tabular}

- Stenderd Irrors are conventional 25 Ls standerd erzors and do not accout for correletion mone parsons lrca the sume bith echools. They are probably understated. 
Ieble $\mathbf{E - 3}$

The Effects of aleh School Curriculv on Wases

Dependant Varieble: Los Averase Bourls

When in 2067 Dollar:

\begin{tabular}{|c|c|c|c|c|c|c|c|c|}
\hline \multirow{3}{*}{ Explanatory Variables } & \multicolumn{8}{|c|}{ Studente in Nonecedenic Prostame } \\
\hline & \multicolumn{4}{|c|}{ as, Bith School Constent Excluded } & \multicolumn{2}{|c|}{ OLS, Hich School } & Constent: & Included \\
\hline & (1) & (2) & (3) & (4) & (5) & (6) & (7) & (8) \\
\hline \multicolumn{9}{|l|}{ scinese venester } \\
\hline hours $(110)$ & -.0093 & -.0043 & -.0030 & -.0043 & -.0020 & -.0024 & -.0038 & -.0047 \\
\hline & $(.0038)$ & $(.0038)$ & $(.0038)$ & $(.0038)$ & $(.0047)$ & $(.0067)$ & $(.0047)$ & $(.0047)$ \\
\hline \multicolumn{9}{|l|}{ FCR. LAHG I conester } \\
\hline bours $(* 10)$ & $\begin{array}{c}.0231 \\
(.0035)\end{array}$ & $\begin{array}{c}.0130 \\
(.0035)\end{array}$ & $\begin{array}{l}.0124 \\
(.0036)\end{array}$ & $\begin{array}{c}.0121 \\
(.0036)\end{array}$ & $\begin{array}{l}.0149 \\
(.0040)\end{array}$ & $\begin{array}{l}.0240 \\
(.0041)\end{array}$ & $\begin{array}{c}.0202 \\
(.0041)\end{array}$ & $\begin{array}{l}.0005 \\
(.0042)\end{array}$ \\
\hline \multicolumn{9}{|l|}{ SOCIAL.ST swerter } \\
\hline hour: $(* 10)$ & $\begin{array}{l}-.0086 \\
(.0039)\end{array}$ & $\begin{array}{l}-.0078 \\
(.0040)\end{array}$ & $\begin{array}{l}-.0058 \\
(.0040)\end{array}$ & $\begin{array}{l}-.0050 \\
(.0040)\end{array}$ & $\begin{array}{l}-.0019 \\
(.0054)\end{array}$ & $\begin{array}{l}=.0010 \\
(.0054)\end{array}$ & $\begin{array}{l}-.0000 \\
(.0054)\end{array}$ & $\begin{array}{l}-.0005 \\
(.0054)\end{array}$ \\
\hline \multicolumn{9}{|l|}{ ENGLISA semester } \\
\hline bours $(110)$ & $\begin{array}{l}-.0150 \\
(.0046)\end{array}$ & $\begin{array}{l}-.0086 \\
(.0046)\end{array}$ & $\begin{array}{l}-.0060 \\
(.0046)\end{array}$ & $\begin{array}{c}.0061 \\
(.0046)\end{array}$ & $\begin{array}{l}-.0098 \\
(.0067)\end{array}$ & $\begin{array}{l}-.0097 \\
(.0067)\end{array}$ & $\begin{array}{l}-.0100 \\
(.0067)\end{array}$ & $\begin{array}{l}-.0204 \\
(.0067)\end{array}$ \\
\hline \multicolumn{9}{|l|}{ MATE enosenter } \\
\hline hour: $(* 10)$ & $\begin{array}{l}.0124 \\
(.0037)\end{array}$ & $\begin{array}{l}.0104 \\
(.0038)\end{array}$ & $\begin{array}{l}.0036 \\
(.0039)\end{array}$ & $\begin{array}{l}.0037 \\
(.0039)\end{array}$ & $\begin{array}{l}.0203 \\
(.0045)\end{array}$ & $\begin{array}{l}.0105 \\
(.0045)\end{array}$ & $\begin{array}{l}.0035 \\
(.0047)\end{array}$ & $\begin{array}{l}.0031 \\
(.0047)\end{array}$ \\
\hline \multicolumn{9}{|l|}{ IND. ARTS semerter } \\
\hline hours $(* 10)$ & $\begin{array}{c}.0164 \\
(.0023)\end{array}$ & $\begin{array}{c}.0108 \\
(.0024)\end{array}$ & $\begin{array}{c}.0105 \\
(.0024)\end{array}$ & $\begin{array}{l}.0111 \\
(.0024)\end{array}$ & $\begin{array}{c}.0124 \\
(.0028)\end{array}$ & $\begin{array}{c}.0125 \\
(.0028)\end{array}$ & $\begin{array}{l}.0125 \\
(.0028)\end{array}$ & $\begin{array}{c}.0134 \\
(.0028)\end{array}$ \\
\hline \multicolumn{9}{|l|}{ COAIDPCIAL seonster } \\
\hline bours $(* 10)$ & $\begin{array}{c}.0033 \\
(.0018)\end{array}$ & $\begin{array}{l}.0043 \\
(.0018)\end{array}$ & $\begin{array}{c}.0036 \\
(.0018)\end{array}$ & $\begin{array}{l}.0036 \\
(.0018)\end{array}$ & $\begin{array}{l}.0060 \\
(.0022)\end{array}$ & $\begin{array}{l}.0056 \\
(.0023)\end{array}$ & $\begin{array}{c}.0036 \\
(.0023)\end{array}$ & $\begin{array}{c}.0036 \\
(.0023)\end{array}$ \\
\hline \multicolumn{9}{|l|}{ FIVE. ARTS s mester } \\
\hline hours $(* 10)$ & $\begin{array}{l}-.0009 \\
(.0023)\end{array}$ & $\begin{array}{l}-.0046 \\
(.0023)\end{array}$ & $\begin{array}{l}-.0048 \\
(.0024)\end{array}$ & $\begin{array}{l}-.0053 \\
(.0024)\end{array}$ & $\begin{array}{l}-.0001 \\
(.0028)\end{array}$ & $\begin{array}{l}-.0001 \\
(.0028)\end{array}$ & $\begin{array}{l}-.0018 \\
(.0028)\end{array}$ & $\begin{array}{l}-.0022 \\
(.0028)\end{array}$ \\
\hline ES. ACAD & -- & 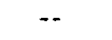 & -- & - & -- & -- & -- & - \\
\hline \multicolumn{9}{|c|}{ Controls for reston, city size } \\
\hline College proximity & No & Yos & $Y \circ$ & $Y \bullet$ & - & -- & -- & -- \\
\hline \multicolumn{9}{|c|}{ Controls for fently backsround } \\
\hline Parental SES variablet & No & No & $Y$ as & Yes & No & Yes & Y॰s & $Y \circ$ \\
\hline $\begin{array}{l}\text { Pareotel involuement and } \\
\text { espirations }\end{array}$ & No & No & $Y=$ & Yes & No & Yes & Yes & Yes \\
\hline $\begin{array}{l}\text { Father, mother wants } \\
\text { collese }\end{array}$ & No & No & Ho & Yes & No & No & No & Yes: \\
\hline $\begin{array}{l}\text { Controls for aptitude and } \\
\text { achieverent }\end{array}$ & No & No & No & Yos & No & No & Yes & Yas \\
\hline
\end{tabular}

- Conventional OLS standard errors in parentheses. These account for degrees of freedom but do not account for serlal correlation over time for the ane person and amons persone from the ame high sehool. They are probabiy understated. 
Table B-64

The effects of Bigh School curriculue on Post secondary Acadenic Education

\section{Dependent Varlable: YRSAC79}

\begin{tabular}{|c|c|c|c|c|c|c|c|c|c|}
\hline \multirow{3}{*}{ Explensecon variasles } & \multicolumn{9}{|c|}{ students in Won-Acedmie Proprese } \\
\hline & \multicolumn{5}{|c|}{ as, High school constane Exeluond th } & \multicolumn{2}{|c|}{ as, nign school } & \multirow{2}{*}{$\frac{\text { Constenes }}{(8)}$} & \multirow{2}{*}{$\frac{1 \times x i n d e d}{(9)}$} \\
\hline & (1) & (2) & (3) & (6) & (s) & (6) & (7) & & \\
\hline setrow sowser & $\begin{array}{l}.0006 \\
(.0217)\end{array}$ & $\begin{array}{l}.0731 \\
(.0206)\end{array}$ & $\begin{array}{l}.0691 \\
(.0200)\end{array}$ & $\begin{array}{l}.0391 \\
(.0190)\end{array}$ & & $\begin{array}{l}.1978 \\
(.0259)\end{array}$ & $\begin{array}{l}.1796 \\
(.0252)\end{array}$ & $\begin{array}{l}.1226 \\
(.02(6)\end{array}$ & $(.0236)$ \\
\hline $\begin{array}{l}\text { fol. Lwe } \\
\text { nowrs }(-10)\end{array}$ & $\begin{array}{l}.3263 \\
(.0198)\end{array}$ & $\begin{array}{l}.2460 \\
(.0193)\end{array}$ & $\begin{array}{l}.1567 \\
(.0180)\end{array}$ & $\begin{array}{l}.1280 \\
(.0181)\end{array}$ & & $(.0220)$ & $\begin{array}{l}.807 \\
(.0219)\end{array}$ & $\begin{array}{l}.1585 \\
(.0219)\end{array}$ & $\begin{array}{l}.1271 \\
8.0210)\end{array}$ \\
\hline $\begin{array}{l}\text { SOCIAL.ST someter } \\
\text { nours }(-10)\end{array}$ & $\begin{array}{l}.0303 \\
(.0226)\end{array}$ & $\begin{array}{l}.0136 \\
(.0217)\end{array}$ & $\begin{array}{l}. .0071 \\
(.0208)\end{array}$ & $\begin{array}{l}-.0096 \\
(.0198)\end{array}$ & & $\begin{array}{l}.0212 \\
(.0296)\end{array}$ & $\begin{array}{l}.0352 \\
(.0288)\end{array}$ & (.028s & $\begin{array}{l}.0293 \\
(.0269)\end{array}$ \\
\hline $\begin{array}{l}\text { EMGLISN semstor } \\
\text { hours }(-10)\end{array}$ & $\begin{array}{l}.0535 \\
(.0263)\end{array}$ & $\begin{array}{l}.0184 \\
(.0252)\end{array}$ & $\begin{array}{l}.0281 \\
(.0263)\end{array}$ & $\begin{array}{l}.0162 \\
(.0231)\end{array}$ & & $.002 \pi)$ & $\begin{array}{l}.0283 \\
(.0366)\end{array}$ & $\begin{array}{l}.0000 \\
(.0355)\end{array}$ & $\begin{array}{l}.0105 \\
(.0341)\end{array}$ \\
\hline $\begin{array}{l}\text { Muik semester } \\
\text { naws (-10) }\end{array}$ & $\begin{array}{l}.2047 \\
8.0210)\end{array}$ & $\begin{array}{l}.1602 \\
(.0202)\end{array}$ & $\begin{array}{l}.0839 \\
6.0200)\end{array}$ & $\begin{array}{l}.0617 \\
(.0191)\end{array}$ & & .2013 & $\begin{array}{l}.2486 \\
(.0238)\end{array}$ & $\begin{array}{l}.1554 \\
(.02(2)\end{array}$ & $\begin{array}{l}.1186 \\
(.0232)\end{array}$ \\
\hline $\begin{array}{l}\text { Ino. Ants somester } \\
\text { nars }(=10)\end{array}$ & $\begin{array}{l}-.0913 \\
(.0162)\end{array}$ & $\begin{array}{l}.0801 \\
(.0025)\end{array}$ & $\begin{array}{l}-.0581 \\
(.0130)\end{array}$ & $\begin{array}{l}-.0538 \\
(.0126)\end{array}$ & & $\begin{array}{l}-.0851 \\
(.0160)\end{array}$ & $\begin{array}{l}-.0586 \\
(.0156)\end{array}$ & $\begin{array}{l}.0060 \\
(.0150)\end{array}$ & $\begin{array}{l}-.02 \pi \\
(.0165)\end{array}$ \\
\hline $\begin{array}{l}\text { CONERC:AL gamester } \\
\text { hours }(\cdot 10)\end{array}$ & $\begin{array}{l}-.0357 \\
(.0101)\end{array}$ & $\begin{array}{l}.0356 \\
(.0098)\end{array}$ & $\begin{array}{l}-.0625 \\
(.0006)\end{array}$ & $\begin{array}{l}-.0302 \\
(.0000)\end{array}$ & & $\begin{array}{l}.0069 \\
(.0121)\end{array}$ & $\begin{array}{l}-.0097 \\
(.0118)\end{array}$ & $\begin{array}{l}-.029 \\
(.0115)\end{array}$ & $\begin{array}{l}-.0227 \\
(.0111)\end{array}$ \\
\hline $\begin{array}{l}\text { PIME. MRTS seneter } \\
\text { hours }(-10)\end{array}$ & $\begin{array}{l}.00(47 \\
(.0133)\end{array}$ & $\begin{array}{l}.0395 \\
(.0128)\end{array}$ & $\begin{array}{l}.0361 \\
(.0126)\end{array}$ & $\begin{array}{l}.0172 \\
(.0018)\end{array}$ & & $\begin{array}{l}.0735 \\
(.0152)\end{array}$ & $\begin{array}{l}.0561 \\
(.0169)\end{array}$ & $\begin{array}{l}.0(35 \\
(.0165)\end{array}$ & $\begin{array}{l}.0305 \\
(.0130)\end{array}$ \\
\hline W5. Acen & $\cdot \cdot$ & $\cdots$ & $\cdots$ & $\because$ & & $\cdots$ & $\because$ & $\cdot \cdot \cdot$ & $\cdots$ \\
\hline Entrots for region, ciey & & & & & & & & & \\
\hline Colloge preximity & yes & res & res & Yes & & $\cdots$ & $\cdots$ & $\cdots$ & $\cdots$ \\
\hline Entrols for fanily bexkgre & & & & & & & & & \\
\hline $\begin{array}{l}\text { Pereneal ses variobles } \\
\text { Pareneal imolvenent and } \\
\text { aspirations }\end{array}$ & No & -bes & Yes & Yes & & no & res & res & res \\
\hline $\begin{array}{l}\text { fother, mother monts } \\
\text { colloge }\end{array}$ & No & no & No & Yes & & no & no & no & res \\
\hline $\begin{array}{l}\text { Controls for sptitud and } \\
\text { chioverent }\end{array}$ & no & No & yes & res & & no & no & res & res \\
\hline
\end{tabular}


Table B-5,3

The effects of High School Curriculue on Post Secondary Acadenic Education

Dependent Variable: YRSAC79

\begin{tabular}{|c|c|c|c|c|c|c|c|c|c|}
\hline \multirow{3}{*}{ Explensecory Veriebles } & \multicolumn{9}{|c|}{ studense in Aceodenic Progrum } \\
\hline & \multicolumn{5}{|c|}{ Ols, wigh School constent Exeludad * } & \multicolumn{2}{|c|}{ ots, Migh school } & \multirow{2}{*}{$\frac{\text { Consemes }}{(8)}$} & \multirow{2}{*}{$\frac{\text { Included }}{(9)}$} \\
\hline & (1) & (2) & (3) & (6) & (5) & (6) & (7) & & \\
\hline $\begin{array}{l}\text { seience semester } \\
\text { nowrs }(=10)\end{array}$ & $\begin{array}{l}.1060 \\
(.0291)\end{array}$ & $\begin{array}{l}.0027 \\
(.0280)\end{array}$ & $\begin{array}{l}.0219 \\
(.0268)\end{array}$ & $\begin{array}{l}.0258 \\
(.0288)\end{array}$ & & $\begin{array}{l}.1600 \\
(.0551)\end{array}$ & $\begin{array}{l}.1310 \\
(.1652)\end{array}$ & $\begin{array}{l}.0267 \\
(.035)\end{array}$ & $\begin{array}{l}.0192 \\
(.0321)\end{array}$ \\
\hline hours $(=10)$ & $\begin{array}{l}.2600 \\
(.0330)\end{array}$ & $\begin{array}{l}.1995 \\
(.0237)\end{array}$ & $\begin{array}{l}.1073 \\
(.0232)\end{array}$ & $\begin{array}{l}.0998 \\
(.0223)\end{array}$ & & $\begin{array}{l}.2851 \\
(.02906)\end{array}$ & $\begin{array}{l}.2615 \\
(.02 x)\end{array}$ & $\begin{array}{l}.1186 \\
(.0280)\end{array}$ & $\begin{array}{l}.0089 \\
(.0270)\end{array}$ \\
\hline 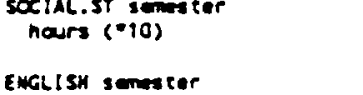 & $\begin{array}{l}. .0521 \\
6.0530)\end{array}$ & $\begin{array}{l}-.0231 \\
(.0317)\end{array}$ & $\begin{array}{l}.0003 \\
(.0303)\end{array}$ & $\begin{array}{l}.0119 \\
(.0291)\end{array}$ & & $\begin{array}{l}.0550 \\
(.0451)\end{array}$ & $\begin{array}{l}.0516 \\
(.0639)\end{array}$ & $\begin{array}{l}.0003 \\
(.02020)\end{array}$ & $\begin{array}{l}.0200 \\
(.0<06)\end{array}$ \\
\hline hours $(=10)$ & $\begin{array}{l}. .0520 \\
(.0610)\end{array}$ & $\begin{array}{l}.0387 \\
(.0393)\end{array}$ & $\begin{array}{l}.0227 \\
(.0377)\end{array}$ & $\begin{array}{l}.0311 \\
(.0362)\end{array}$ & & $\begin{array}{l}.0058 \\
(.0586)\end{array}$ & $\begin{array}{l}.0085 \\
(.0572)\end{array}$ & $\begin{array}{l}.0020 \\
(.0567)\end{array}$ & $\begin{array}{l}.0592 \\
(.0526)\end{array}$ \\
\hline $\begin{array}{l}\text { MATH semester } \\
\text { hours }(-10) \\
\text { ho }\end{array}$ & $\begin{array}{l}.2820 \\
. .0329)\end{array}$ & $\begin{array}{l}.243 \\
(.0318)\end{array}$ & $\begin{array}{l}.1169 \\
(.0317)\end{array}$ & $\begin{array}{l}.0906 \\
(.0304)\end{array}$ & & $\begin{array}{l}.3597 \\
(.0306)\end{array}$ & $\begin{array}{l}.3261 \\
(.0077)\end{array}$ & $\begin{array}{l}.1567 \\
(.0381)\end{array}$ & $\begin{array}{l}.1262 \\
(.0367)\end{array}$ \\
\hline cowerctal semester & $\begin{array}{l}-.1836 \\
(.0298)\end{array}$ & $\begin{array}{l}-.1630 \\
(.0287)\end{array}$ & $\begin{array}{l}-.1056 \\
(.023)\end{array}$ & $\frac{.0066}{6.0266)}$ & & $\begin{array}{l}.1921 \\
(.0326)\end{array}$ & $\begin{array}{l}-.1718 \\
(.0337)\end{array}$ & $\begin{array}{l}-.1236 \\
(.0326)\end{array}$ & $\begin{array}{l}-.102 \\
i .0312\}\end{array}$ \\
\hline nours $(-10)$ & $\begin{array}{l}-1287 \\
(.0265)\end{array}$ & $\begin{array}{l}-.0876 \\
(.0237)\end{array}$ & $\begin{array}{l}-.0659 \\
(.0227)\end{array}$ & $\begin{array}{l}-.0390 \\
(.0298)\end{array}$ & & $\begin{array}{l}-1116 \\
8.0300)\end{array}$ & $\begin{array}{l}.00055 \\
(.02 \times(4)\end{array}$ & $\begin{array}{l}-.0552 \\
(.0282)\end{array}$ & $\begin{array}{l}.058 \\
(.0271)\end{array}$ \\
\hline $\begin{array}{l}\text { FIME. MRTS somes ter } \\
\text { nourz }(-10)\end{array}$ & $\begin{array}{l}.0656 \\
(.0178)\end{array}$ & $\begin{array}{l}.0167 \\
(.0172)\end{array}$ & $\begin{array}{l}.0169 \\
(.0166)\end{array}$ & $\begin{array}{l}.0160 \\
(.0157)\end{array}$ & & $\begin{array}{l}.0306 \\
(.0215)\end{array}$ & $\begin{array}{l}.0149 \\
(.0211)\end{array}$ & $\begin{array}{l}-.0016 \\
(.0202)\end{array}$ & $\begin{array}{l}.0006 \\
(.018)\end{array}$ \\
\hline HS.ACNO & $\cdots$ & $\cdots$ & $\cdots$ & $\cdots$ & & $\cdots$ & $\because$ & $\cdots$ & $\because$ \\
\hline Contrals for region, city siz & & & & & & & & & \\
\hline College proximity & $\because \in s$ & res & in & yes & & $\cdots$ & $\cdots$ & $\cdots$ & $\cdots$ \\
\hline Conerols for femily bexegran & & & & & & & & & \\
\hline Pareneal SES varieteles & Mo & $y \in S$ & Ym & Yes & & Mo & res & Yes & res \\
\hline $\begin{array}{l}\text { Parental imolvenent and } \\
\text { aspirations }\end{array}$ & Mo & Yes & Yes & Yes & & No & res & res & res \\
\hline Fother, mother ments college & no & xo & no & Yes & & no & No & No & res \\
\hline $\begin{array}{l}\text { Controls for eptitude and } \\
\text { sechienment }\end{array}$ & No & no & $x_{s}$ & res & & no & Ho & Yes & res \\
\hline
\end{tabular}


Ioblo I-2

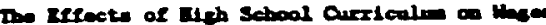
Depodent Verioblo: Los Avarage Boar1s

when in 1057 Doulars

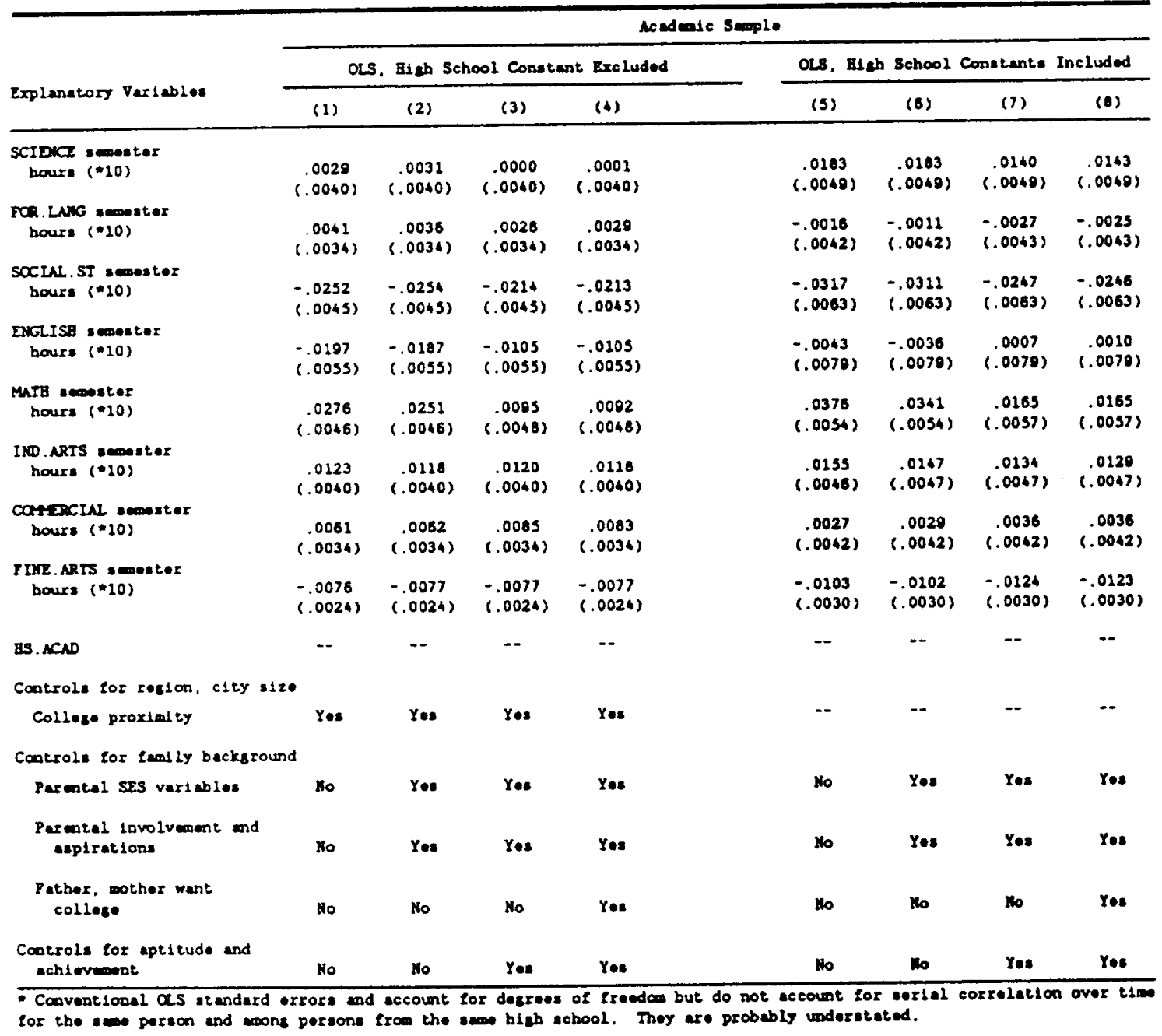

